\title{
Impact of different fertilizers on carbonate weathering in a typical karst area, Southwest China: a field column experiment
}

\author{
Chao Song ${ }^{1,2}$, Changli Liu ${ }^{1}$, Guilin Han ${ }^{2}$, and Congqiang Liu ${ }^{2}$ \\ ${ }^{1}$ The Institute of Hydrogeology and Environmental Geology, Chinese Academy of Geological Sciences, \\ Shijiazhuang, 050803, Hebei, China \\ ${ }^{2}$ School of Water Resources and Environment, China University of Geosciences (Beijing), \\ Beijing, 100083, China \\ Correspondence to: Chao Song (chao-song@qq.com)
}

Received: 17 September 2016 - Discussion started: 4 October 2016

Revised: 28 June 2017 - Accepted: 30 August 2017 - Published: 26 September 2017

\begin{abstract}
Carbonate weathering, as a significant vector for the movement of carbon both between and within ecosystems, is strongly influenced by agricultural fertilization, since the addition of fertilizers tends to change the chemical characteristics of soil such as the $\mathrm{pH}$. Different fertilizers may exert a different impact on carbonate weathering, but these discrepancies are as yet not well-known. In this study, a field column experiment was conducted to explore the response of carbonate weathering to the addition of different fertilizers. We compared 11 different treatments, including a control treatment, using three replicates per treatment. Carbonate weathering was assessed by measuring the weight loss of limestone and dolostone tablets buried at the bottom of soil-filled columns. The results show that the addition of urea, $\mathrm{NH}_{4} \mathrm{NO}_{3}, \mathrm{NH}_{4} \mathrm{HCO}_{3}, \mathrm{NH}_{4} \mathrm{Cl}$ and $\left(\mathrm{NH}_{4}\right)_{2} \mathrm{CO}_{3}$ distinctly increased carbonate weathering, which was attributed to the nitrification of $\mathrm{NH}_{4}^{+}$. The addition of $\mathrm{Ca}_{3}\left(\mathrm{PO}_{4}\right)_{2}$, $\mathrm{Ca}-\mathrm{Mg}-\mathrm{P}$ and $\mathrm{K}_{2} \mathrm{CO}_{3}$ induced carbonate precipitation due to the common ion effect. The addition of $\left(\mathrm{NH}_{4}\right)_{3} \mathrm{PO}_{4}$ and $\mathrm{NaNO}_{3}$ had a relatively small impact on carbonate weathering in comparison to those five $\mathrm{NH}_{4}$-based fertilizers above. The results of $\mathrm{NaNO}_{3}$ treatment raise a new question: the negligible impact of nitrate on carbonate weathering may result in an overestimation of the impact of $\mathrm{N}$ fertilizer on $\mathrm{CO}_{2}$ consumption by carbonate weathering on the regional/global scale if the effects of $\mathrm{NO}_{3}$ and $\mathrm{NH}_{4}$ are not distinguished.
\end{abstract}

\section{Introduction}

Carbonate weathering plays a significant role in the consumption of atmospheric $\mathrm{CO}_{2}$ (Kump et al., 2000; Liu et al., 2011, 2010). Riverine hydro-chemical composition, such as the ratio of $\mathrm{HCO}_{3}^{-}$to $\mathrm{Ca}^{2+}+\mathrm{Mg}^{2+}$, is usually employed as an indicator to estimate the $\mathrm{CO}_{2}$ consumption by natural carbonate weathering on the regional/global scale (Hagedorn and Cartwright, 2009; Li et al., 2009). However, fluvial alkalinity may also be produced by other processes including the reaction between carbonates and protons derived from (i) the nitrification of $\mathrm{N}$ fertilizer (Barnes and Raymond, 2009; Gandois et al., 2011; Hamilton et al., 2007; Oh and Raymond, 2006; Perrin et al., 2008; Pierson-wickmann et al.,
2009; Semhi and Suchet, 2000; Song et al., 2017a, 2011; West and McBride, 2005); (ii) sulfuric acid forming in the oxidation of reduced sulfuric minerals (mainly pyrite, $\mathrm{FeS}_{2}$ ) (Lerman and Wu, 2006; Lerman et al., 2007; Li et al., 2011, 2008); (iii) organic acid secreted by microorganisms (Lian et al., 2008); and (iv) acidic soil (such as red soil and yellow soil) (Song et al., 2014, 2017b). Given that atmospheric $\mathrm{CO}_{2}$ is not a unique weathering agent, differentiating between the agents of carbonate weathering is important for the accurate budgeting of net $\mathrm{CO}_{2}$ consumption by carbonate weathering, especially in agricultural areas where mineral fertilizers are used.

The global average annual increase in mineral fertilizer consumption was $3.3 \%$ from 1961 to 1997 , and the FAO's 


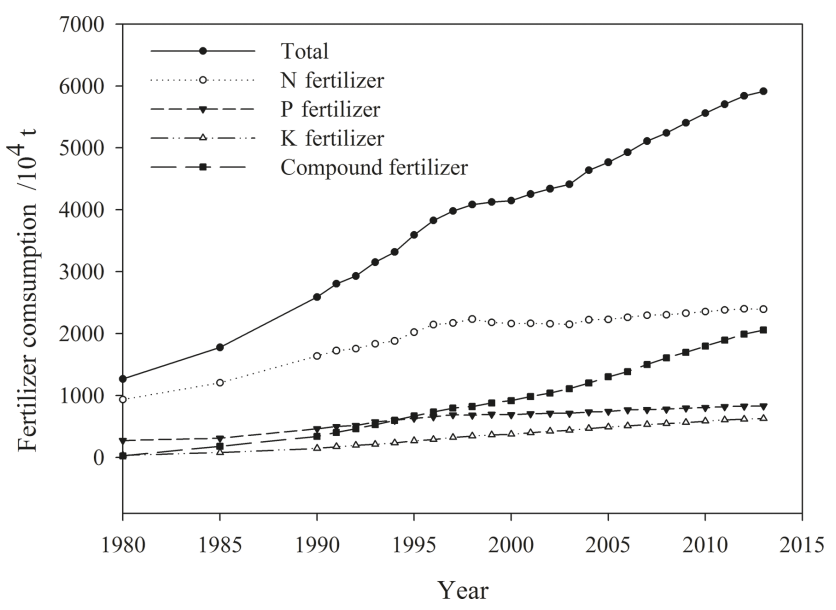

Figure 1. The change in chemical fertilizer consumption in China during the 1980-2013 period. The data were collected from the National Bureau of Statistics of the People's Republic of China (NBS, 2014) (http://www.stats.gov.cn/tjsj/ndsj/).

study predicts a $1 \%$ increase per year until 2030 (FAO, 2000). In China, the consumption of chemical fertilizer increased from $12.7 \mathrm{Mt}$ in 1980 to $59.1 \mathrm{Mt}$ in 2013 (Fig. 1). The increasing consumption of mineral fertilizers is a significant disturbance factor in carbonate weathering and the carbon cycle. Several studies have shown that nitrogen fertilizer additions increased weathering rates and also increased the total export of DIC (dissolved inorganic carbon) from agricultural watersheds (Barnes and Raymond, 2009; Gandois et al., 2011; Hamilton et al., 2007; Oh and Raymond, 2006; Perrin et al., 2008; Pierson-wickmann et al., 2009; Probst, 1986; Semhi and Suchet, 2000; West and McBride, 2005). According to an estimate by Semhi et al. (2000), the contribution of $\mathrm{N}$ fertilizers to carbonate dissolution was 30 and $12-26 \%$ in two small agricultural carbonate basins in southwestern France: the Girou and the Gers, respectively (tributaries of the Garonne River). In the Garonne River basin, which is a large basin $\left(52000 \mathrm{~km}^{2}\right)$, this contribution was estimated to be $6 \%$ by Semhi et al. (2000). Perrin et al. (2008) estimated that the contribution of $\mathrm{N}$ fertilizer (usually in the form of $\mathrm{NH}_{4} \mathrm{NO}_{3}$ ) represents up to 5.7-13.4 and 1.6-3.8\% of the carbonate dissolution in France and across the world, respectively.

The estimates described above are largely based on calculations that assumed that a single type of fertilizer (e.g., $\left(\mathrm{NH}_{4}\right)_{2} \mathrm{SO}_{4}, \mathrm{NH}_{4} \mathrm{NO}_{3}$ or $\mathrm{NH}_{4} \mathrm{Cl}$ ) was used throughout the whole basin that was considered. However, in actual agricultural practice, different fertilizers are usually added for different crops. The impact of these fertilizers on carbonate weathering and riverine chemical composition may be different. In the case of nitrogenous fertilizer, $100 \%$ of $\mathrm{NO}_{3}^{-}$produced after the addition of $\left(\mathrm{NH}_{4}\right)_{2} \mathrm{SO}_{4}$ and $\mathrm{NH}_{4} \mathrm{Cl}$ is derived from the nitrification of $\mathrm{NH}_{4}^{+}$, whilst comparatively, it is only $50 \%$ after the addition of $\mathrm{NH}_{4} \mathrm{NO}_{3}$. Differences in $\mathrm{NO}_{3}^{-}$ sources may produce a deviation in the impact of $\mathrm{N}$ fertilizer addition on $\mathrm{CO}_{2}$ consumption by carbonate weathering, since the addition of different $\mathrm{N}$ fertilizers (e.g., $\left(\mathrm{NH}_{4}\right)_{2} \mathrm{SO}_{4}$, $\mathrm{NH}_{4} \mathrm{NO}_{3}, \mathrm{NH}_{4} \mathrm{Cl}, \mathrm{NaNO}_{3}$ or urea) may result in different contributions to carbonate weathering and relative products such as $\mathrm{HCO}_{3}^{-}, \mathrm{Ca}^{2+}$ and $\mathrm{Mg}^{2+}$. For phosphate fertilizer, the coprecipitation of phosphate ions with calcium carbonate may inhibit carbonate weathering (Kitano et al., 1978). We assume that the response of carbonate weathering to the addition of different fertilizers, such as $\mathrm{N}$ fertilizer $\left(\mathrm{NH}_{4}\right.$ and $\mathrm{NO}_{3}$ ), $\mathrm{P}$ fertilizer and $\mathrm{Ca} / \mathrm{Mg}$ fertilizer, may display differences, which are so far poorly known but likely significant. Here we sought to understand the agricultural impact on natural carbonate weathering and to accurately evaluate the $\mathrm{CO}_{2}$ consumption via carbonate weathering in agricultural areas.

The carbonate rock-tablet test is used to determine the weathering rate of carbonate rock/mineral from the laboratory to the field (Adams and Post, 1999; Dreybrodt et al., 1996; Gams, 1981, 1985; Jiang and Yuan, 1999; Liu and Dreybrod, 1997; Plan, 2005; Song et al., 2017a, b, 2011; Trudgill, 1975). In the laboratory, the carbonate rock tablet is employed to study the kinetics of calcite dissolution/precipitation (Dreybrodt et al., 1996; Liu and Dreybrod, 1997) and determine the rate of carbonate mineral weathering in the soil column (Song et al., 2017a, 2011). In the field, it is also used to observe the rate of carbonate weathering and estimate $\mathrm{CO}_{2}$ consumption (Jiang, 2013; Jiang and Yuan, 1999; Plan, 2005; Song et al., 2017a, b, 2011). Liu (2011) argued that the carbonate rock-tablet test may lead to deviations in estimated $\mathrm{CO}_{2}$ consumption by carbonate weathering on the regional/global scale, in cases where there are insufficient representative data. It is nonetheless a wellestablished method for a comparative or simulated experiment (Song et al., 2017a, b, 2011).

A field column experiment that involved embedding carbonate rock tablets was carried out in a typical karst area of southwest China, in order to observe the impact of different fertilizer additions on carbonate weathering in soil.

\section{Materials and methods}

\subsection{The study site}

This study was carried out in a typical karst area, namely the Huaxi District of Guiyang City, Guizhou Province, SW China $\left(26^{\circ} 23^{\prime} \mathrm{N}, 106^{\circ} 40^{\prime} \mathrm{E}\right.$; 1094 ma.s.l.). Guiyang, the capital city of Guizhou Province, is located in the central part of the province, covering an area from $26^{\circ} 11^{\prime} 00^{\prime \prime}$ to $26^{\circ} 54^{\prime} 20^{\prime \prime} \mathrm{N}$ and $106^{\circ} 27^{\prime} 20^{\prime \prime}$ to $107^{\circ} 03^{\prime} 00^{\prime \prime} \mathrm{E}$ (approximately $8000 \mathrm{~km}^{2}$ ), with elevations ranging from 875 to $1655 \mathrm{~m}$ a.s.l. Guiyang has a population of more than $1.5 \mathrm{mil}-$ lion people, a wide diversity of karstic landforms, high elevations and low latitude, with a subtropical warm-moist climate, an average annual temperature of $15.3^{\circ} \mathrm{C}$ and an annual precipitation of $1200 \mathrm{~mm}$ (Lang, 2006). A monsoonal 
climate often results in high precipitation during summer, with much less during winter, although the humidity is often high throughout most of the year (Han and Jin, 1996). Agriculture is a major land use in order to produce the vegetables and foods in the suburbs of Guiyang (Liu et al., 2006). The consumption of chemical fertilizer increased from $150 \mathrm{kgha}^{-1}$ in 1980 to $190 \mathrm{kgha}^{-1}$ in 2013 (GBS, 2014).

\subsection{Soil properties}

The soil used in this column experiment was yellow-brown clay, which was sampled from the B horizon (below $20 \mathrm{~cm}$ in depth) of a yellow-brown soil profile from a cabbagecorn or capsicum-corn rotation plantation in Huaxi District. The soil was air-dried, ground to pass through a $2 \mathrm{~mm}$ sieve, mixed thoroughly and used for the soil columns. The soil $\mathrm{pH}\left(V_{\text {soil }}: V_{\text {water }}=1: 2.5\right)$ was determined by $\mathrm{pH}$ meter. The chemical characteristics of the soil, including organic matter $(\mathrm{OM}), \mathrm{NH}_{4}-\mathrm{N}, \mathrm{NO}_{3}-\mathrm{N}$, available $\mathrm{P}$, available $\mathrm{K}$, available $\mathrm{Ca}$, available $\mathrm{Mg}$, available $\mathrm{Fe}$ and available $\mathrm{S}$ were determined according to the Agro Services International (ASI) method (Hunter, 1984). OM was extracted by using an extracting solution containing $0.2 \mathrm{molL}^{-1} \mathrm{NaOH}$, $0.01 \mathrm{~mol} \mathrm{~L}^{-1}$ EDTA (ethylene diamine tetraacetic acid), $2 \%$ methanol and $0.005 \%$ Superfloc 127 and determined by the $\mathrm{K}_{2} \mathrm{CrO}_{7}-\mathrm{H}_{2} \mathrm{SO}_{4}$ oxidation method. $\mathrm{NH}_{4}-\mathrm{N}, \mathrm{NO}_{3}-\mathrm{N}$, available $\mathrm{Ca}$ and $\mathrm{Mg}$ were extracted by $1 \mathrm{molL}^{-1} \mathrm{KCl}$ solution. $\mathrm{NH}_{4}-\mathrm{N}$ and $\mathrm{NO}_{3}-\mathrm{N}$ was determined by the colorimetry method, while $\mathrm{Ca}$ and $\mathrm{Mg}$ were determined by ICPAES (inductively coupled plasma atomic emission spectrometer). Available $\mathrm{K}, \mathrm{P}$ and $\mathrm{Fe}$ were extracted by using an extracting solution containing $0.25 \mathrm{molL}^{-1} \mathrm{NaHCO}_{3}$, $0.01 \mathrm{molL}^{-1}$ EDTA, $0.01 \mathrm{molL}^{-1} \mathrm{NH}_{4} \mathrm{~F}$ and $0.005 \% \mathrm{Su}-$ perfloc 127. $\mathrm{P}$ was determined by spectrophotometry (colorimetry), and $\mathrm{K}$ and $\mathrm{Fe}$ were determined by atomic absorption spectrophotometry. Finally, available $\mathrm{S}$ was extracted by $0.1 \mathrm{moll}^{-1} \mathrm{Ca}\left(\mathrm{H}_{2} \mathrm{PO}_{4}\right)_{2}$ and $0.005 \%$ Superfloc 127 and determined by the turbidimetric method. The results are shown in Table 1.

\subsection{Soil column and different fertilization treatments}

In order to test the hypothesis that the impact of different chemical fertilizers on carbonate weathering may be different, columns $(\varnothing=20 \mathrm{~cm} ; H=15 \mathrm{~cm})$ were constructed from a $20 \mathrm{~cm}$ diameter polyvinyl chloride (PVC) pipe (Fig. 2). A hole $(\varnothing=2 \mathrm{~cm})$ was placed at the bottom of each column to discharge soil water from the soil column. A polyethylene net $(\varnothing 0.5 \mathrm{~mm})$ was placed in the bottom of the columns to prevent soil loss. A $2 \mathrm{~cm}$ thick filter layer, including gravel, coarse sand and fine sand, was spread over the net. Two different carbonate rock tablets were buried at the bottom of each soil column (Fig. 2). Based on the common kinds of chemical fertilizers and the main objective
Table 1. Chemical composition of soil.

\begin{tabular}{llr}
\hline Parameter & Unit & Values \\
\hline $\mathrm{pH}$ & - & 6.94 \\
Content of particles $<0.01 \mathrm{~mm}$ & $\%$ & 74 \\
Content of particles $<0.001 \mathrm{~mm}$ & $\%$ & 45 \\
Organic matter & $\%$ & 0.99 \\
$\mathrm{NH}_{4}^{+}-\mathrm{N}$ & $\mathrm{mg} \mathrm{kg}^{-1}$ & 339.87 \\
$\mathrm{NO}_{3}^{-}-\mathrm{N}$ & $\mathrm{mg} \mathrm{kg}^{-1}$ & 569.05 \\
Available $\mathrm{P}$ & $\mathrm{mg} \mathrm{kg}^{-1}$ & 8.18 \\
Available K & $\mathrm{mg} \mathrm{kg}^{-1}$ & 56.88 \\
Available Ca & $\mathrm{mg} \mathrm{kg}^{-1}$ & 3041.06 \\
Available $\mathrm{Mg}$ & $\mathrm{mg} \mathrm{kg}^{-1}$ & 564.83 \\
Available S & $\mathrm{mg} \mathrm{kg}^{-1}$ & 100.72 \\
Available Fe & $\mathrm{mg} \mathrm{kg}^{-1}$ & 24.41 \\
\hline
\end{tabular}

of this study, three types (N, P and $\mathrm{K}$ fertilizers) of fertilizer including 10 different fertilizers $\left(\mathrm{NH}_{4} \mathrm{NO}_{3} ; \mathrm{NH}_{4} \mathrm{HCO}_{3}\right.$; $\mathrm{NaNO}_{3} ; \mathrm{NH}_{4} \mathrm{Cl} ;\left(\mathrm{NH}_{4}\right)_{2} \mathrm{CO}_{3} ; \mathrm{Ca}_{3}\left(\mathrm{PO}_{4}\right)_{2} ;\left(\mathrm{NH}_{4}\right)_{3} \mathrm{PO}_{4}$; fused calcium-magnesium phosphate; urea; and $\mathrm{K}_{2} \mathrm{CO}_{3}$ fertilizer) were involved in this study. As a result, 11 fertilization treatments including the control treatment, each with three replicates, were set up in the field column experiment. The local practical rate of fertilizer application is approximately $160 \mathrm{~kg} \mathrm{Nha}^{-1}$ of $\mathrm{N}$ fertilizer, $150 \mathrm{~kg} \mathrm{P}_{2} \mathrm{O}_{5} \mathrm{ha}^{-1}$ of $\mathrm{P}$ fertilizer and $50 \mathrm{~kg} \mathrm{Kha}^{-1}$ of $\mathrm{K}$ fertilizer. In order to shorten the time of this experiment and make the experimental results distinct, the added amount of 10 fertilizers was increased to (1) control without fertilizer (CK); (2) $43 \mathrm{~g} \mathrm{NH}_{4} \mathrm{NO}_{3}$ fertilizer (CF); (3) $85 \mathrm{~g} \mathrm{NH}_{4} \mathrm{HCO}_{3}$ fertilizer (NHC); (4) $91 \mathrm{~g}$ $\mathrm{NaNO}_{3}$ fertilizer (NN); (5) $57 \mathrm{~g} \mathrm{NH}_{4} \mathrm{Cl}$ fertilizer (NCL); (6) $51 \mathrm{~g}\left(\mathrm{NH}_{4}\right)_{2} \mathrm{CO}_{3}$ fertilizer (NC); (7) $52 \mathrm{~g} \mathrm{Ca}_{3}\left(\mathrm{PO}_{4}\right)_{2}$ fertilizer (CP); (8) $15 \mathrm{~g}\left(\mathrm{NH}_{4}\right)_{3} \mathrm{PO}_{4}$ fertilizer (NP); (9) $44 \mathrm{~g}$ fused calcium-magnesium phosphate fertilizer $(\mathrm{Ca}-\mathrm{Mg}-\mathrm{P})$; (10) $32 \mathrm{~g}$ urea fertilizer (U); and (11) $10 \mathrm{~g} \mathrm{~K}_{2} \mathrm{CO}_{3}$ fertilizer (PP). An aliquot of $6 \mathrm{~kg}$ of soil was weighed (bulk density $=1.3 \mathrm{~g} \mathrm{~cm}^{-3}$ ), mixed thoroughly with one of the above fertilizers and filled into its own column. This process was repeated for all three replicates of the 11 fertilizer treatments. The soil columns were labeled and put in place in an orderly fashion (see Fig. 2b) at the field experiment site in Huaxi District, Guiyang for a whole year.

\subsection{The rate of carbonate weathering}

Two different kinds of carbonate rock tablets $(2 \mathrm{~cm} \times 1 \mathrm{~cm} \times$ $0.5 \mathrm{~cm}$ in size) were placed in the bottom of each soil column to examine the rate of carbonate weathering in the soil. The two different kinds of carbonate rock collected from the karst area of Huaxi District were (1) limestone with 60-65\% micrite, 30-35\% microcrystalline calcite and 2-3\% pyrite; and (2) dolostone with $98-99 \%$ fine crystalline dolomite, $1 \%$ pyrite, and trace quantities organic matter. All the tablets were heated at $80^{\circ} \mathrm{C}$ for $4 \mathrm{~h}$, weighed on a $1 / 10000$ elec- 


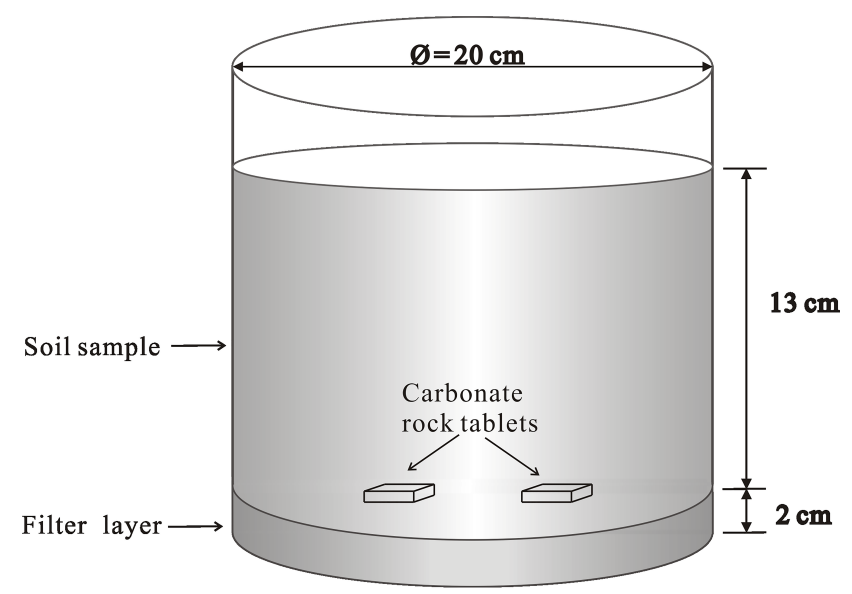

(a)

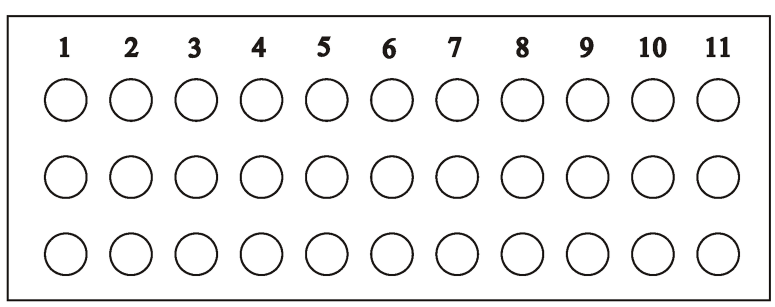

(b)

Figure 2. Sketch of the soil column (a) and their on-site layout (b). (a) The filter layer ( $2 \mathrm{~cm}$ thick) consists of gravel, coarse sand and fine sand; (b) 11 fertilization treatments with 3 replicates including the following: 1 - control; $2-\mathrm{NH}_{4} \mathrm{NO}_{3} ; 3-\mathrm{NH}_{4} \mathrm{HCO}_{3}$; $4-\mathrm{NaNO}_{3} ; 5-\mathrm{NH}_{4} \mathrm{Cl} ; 6-\left(\mathrm{NH}_{4}\right)_{2} \mathrm{CO}_{3} ; 7-\mathrm{Ca}_{3}\left(\mathrm{PO}_{4}\right)_{2} ; 8-$ $\left(\mathrm{NH}_{4}\right)_{3} \mathrm{PO}_{4} ; 9-\mathrm{Ca}-\mathrm{Mg}-\mathrm{P} ; 10-$ urea; $11-\mathrm{K}_{2} \mathrm{CO}_{3}$.

tronic balance in the laboratory, labeled by tying a label with fishing line and then buried at the bottom of each soil column. After a whole year, the tablets were removed carefully, rinsed, baked and weighed.

The amount of weathering $\left(A_{\mathrm{w}}\right)$, the ratio of weathering $\left(R_{\mathrm{W}}\right)$ and the rate of weathering $\left(R_{\mathrm{aw}}\right)$ for limestone and dolomite were calculated according to the weight difference of the tablets using the following formulas:

$A_{\mathrm{w}}=\left(W_{\mathrm{i}}-W_{\mathrm{f}}\right)$,

$R_{\mathrm{W}}=\left(W_{\mathrm{i}}-W_{\mathrm{f}}\right) / W_{\mathrm{i}}$,

$R_{\mathrm{aw}}=\left(W_{\mathrm{i}}-W_{\mathrm{f}}\right) /(S \times T)$,

where $W_{\mathrm{i}}$ is the initial weight of the carbonate rock tablet, $W_{\mathrm{f}}$ is the final weight, $S$ is the surface area of the carbonate rock tablet and $T$ is the length of the experimental period.

\subsection{Statistical analysis}

Statistical analysis was performed using IBM SPSS 20.0 (Statistical Graphics Corp, Princeton, USA). All results of carbonate weathering were reported as the means \pm standard deviations (SDs) for the three replicates.
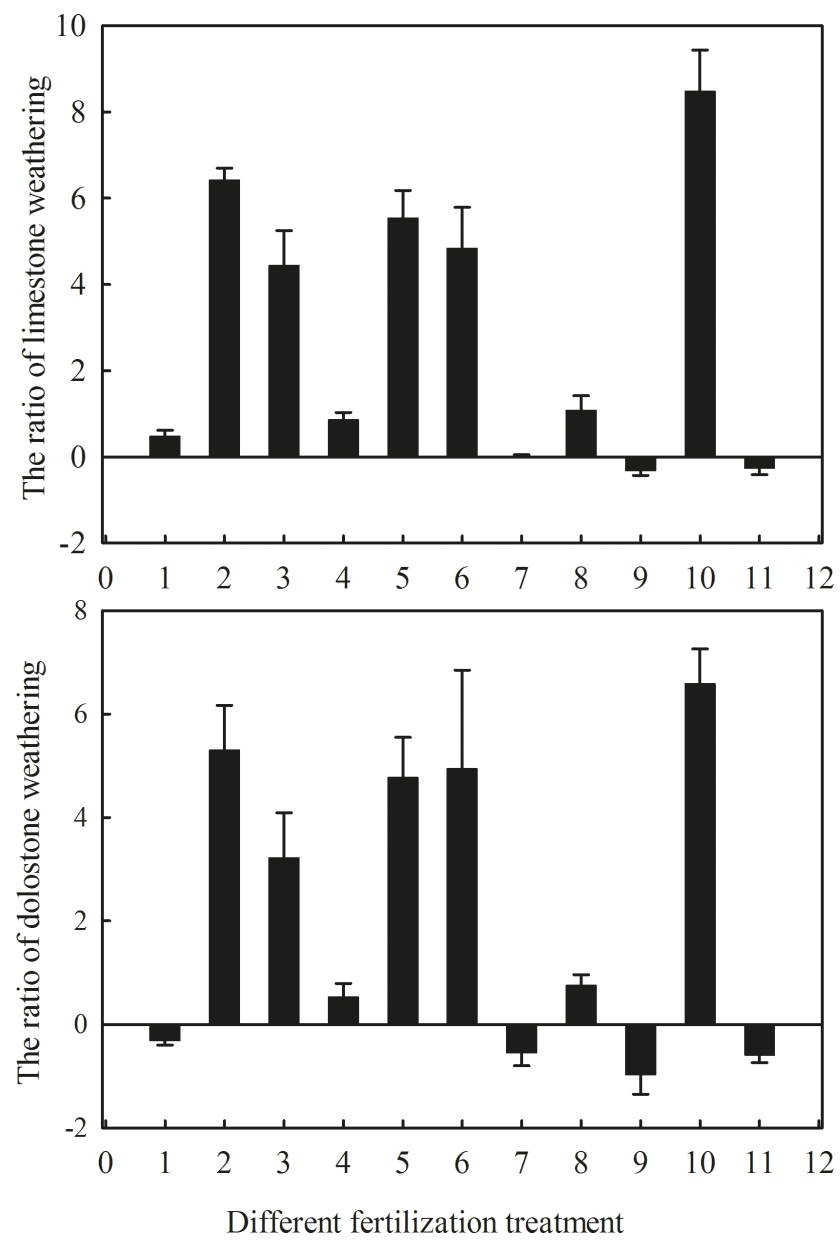

Figure 3. The $R_{\mathrm{W}}(\% \circ)$ of limestone and dolostone under different fertilizer treatments: 1 - control; $2-\mathrm{NH}_{4} \mathrm{NO}_{3} ; 3-\mathrm{NH}_{4} \mathrm{HCO}_{3}$; $4-\mathrm{NaNO}_{3} ; 5-\mathrm{NH}_{4} \mathrm{Cl} ; 6-\left(\mathrm{NH}_{4}\right)_{2} \mathrm{CO}_{3} ; 7-\mathrm{Ca}_{3}\left(\mathrm{PO}_{4}\right)_{2} ; 8$ - $\left(\mathrm{NH}_{4}\right)_{3} \mathrm{PO}_{4} ; 9-\mathrm{Ca}-\mathrm{Mg}-\mathrm{P} ; 10$ - urea; $11-\mathrm{K}_{2} \mathrm{CO}_{3} . R_{\mathrm{W}}=$ $1000\left(W_{\mathrm{i}}-W_{\mathrm{f}}\right) / W_{\mathrm{i}}$, where $W_{\mathrm{i}}$ is the initial weight of the carbonate rock tablet and $W_{\mathrm{f}}$ is the final weight.

\section{Results}

\subsection{Weathering rate of carbonate under different fertilized treatments}

The $R_{\mathrm{w}}$ and $R_{\mathrm{aw}}$ of limestone and dolostone are listed in Table 2. The results show that the $R_{\mathrm{w}}$ of limestone under urea, $\mathrm{NH}_{4} \mathrm{NO}_{3}, \mathrm{NH}_{4} \mathrm{Cl},\left(\mathrm{NH}_{4}\right)_{2} \mathrm{CO}_{3}$ and $\mathrm{NH}_{4} \mathrm{HCO}_{3}$ treatments was $8.48 \pm 0.96,6.42 \pm 0.28,5.54 \pm 0.64,4.44 \pm 0.81$ and $4.48 \pm 0.95 \%$, respectively, significantly greater than that under the control treatment $(0.48 \pm 0.14 \%$; see Fig. 3$)$. In addition, the observed $R_{\mathrm{w}}$ of dolostone was $6.59 \pm 0.67$, $5.30 \pm 0.87,4.77 \pm 0.78,4.94 \pm 1.91$ and $3.22 \pm 0.87 \%$ orespectively, under these same five fertilization treatments, in contrast to $-0.31 \pm 0.09 \%$ in the control treatment. This clearly demonstrates that the addition of these five fertilizers increased the rate of carbonate weathering. 
Table 2. Carbonate weathering under different fertilizer treatments.

\begin{tabular}{lrrrr}
\hline Treatment & \multicolumn{2}{c}{ Limestone } & \multicolumn{2}{c}{ Dolostone } \\
& $R_{\mathrm{W}} / \%$ o & \multicolumn{1}{c}{$R_{\mathrm{aw}} / \mathrm{g} \mathrm{m}^{-2} \mathrm{a}^{-1}$} & $R_{\mathrm{W}} / \%$ o & $R_{\mathrm{aw}} / \mathrm{g} \mathrm{m}^{-2} \mathrm{a}^{-1}$ \\
\hline $\mathrm{Control}$ & $0.48 \pm 0.14$ & $2.00 \pm 0.58$ & $-0.31 \pm 0.09$ & $-1.57 \pm 0.86$ \\
$\mathrm{NH}_{4} \mathrm{NO}_{3}$ & $6.42 \pm 0.28$ & $24.86 \pm 2.01$ & $5.30 \pm 0.87$ & $20.57 \pm 1.15$ \\
$\mathrm{NH}_{4} \mathrm{HCO}_{3}$ & $4.44 \pm 0.81$ & $21.00 \pm 3.45$ & $3.22 \pm 0.87$ & $13.71 \pm 3.88$ \\
$\mathrm{NaNO}_{3}$ & $0.86 \pm 0.17$ & $4.43 \pm 1.73$ & $0.53 \pm 0.26$ & $3.14 \pm 1.73$ \\
$\mathrm{NH}_{4} \mathrm{Cl}$ & $5.54 \pm 0.64$ & $21.29 \pm 2.45$ & $4.77 \pm 0.78$ & $18.71 \pm 0.86$ \\
$\left(\mathrm{NH}_{4}\right)_{2} \mathrm{CO}_{3}$ & $4.48 \pm 0.95$ & $20.57 \pm 4.46$ & $4.94 \pm 1.91$ & $26.57 \pm 7.62$ \\
$\mathrm{Ca}_{3}\left(\mathrm{PO}_{4}\right)_{2}$ & $0.01 \pm 0.04$ & $0.43 \pm 0.86$ & $-0.55 \pm 0.25$ & $-1.86 \pm 1.29$ \\
$\left(\mathrm{NH}_{4}\right)_{3} \mathrm{PO}_{4}$ & $1.08 \pm 0.34$ & $4.00 \pm 1.15$ & $0.75 \pm 0.21$ & $1.00 \pm 1.01$ \\
$\mathrm{Ca}-\mathrm{Mg}-\mathrm{P}$ & $-0.31 \pm 0.12$ & $-1.86 \pm 0.43$ & $-0.97 \pm 0.38$ & $-3.14 \pm 0.72$ \\
$\mathrm{Urea}$ & $8.48 \pm 0.96$ & $34.71 \pm 4.32$ & $6.59 \pm 0.67$ & $26.43 \pm 2.73$ \\
$\mathrm{~K}_{2} \mathrm{CO}_{3}$ & $-0.26 \pm 0.15$ & $-1.14 \pm 0.58$ & $-0.59 \pm 0.15$ & $-2.57 \pm 0.43$ \\
\hline
\end{tabular}

$R_{\mathrm{W}}$ - the ratio of carbonate weathering; $R_{\mathrm{aw}}$ - the rate of carbonate weathering; $R_{\mathrm{W}}=1000\left(W_{\mathrm{i}}-W_{\mathrm{f}}\right) / W_{\mathrm{i}}$ and $R_{\text {aw }}=\left(W_{\mathrm{i}}-W_{\mathrm{f}}\right) /(S \times T)$, where $W_{\mathrm{i}}$ is the initial weight of the carbonate rock tablet and $W_{\mathrm{f}}$ is the final weight. $\mathrm{S}$ is the surface area of the carbonate rock tablet (here, we used $S=7 \mathrm{~cm}^{2}$ for every tablet), and $T$ is the experiment period. Values are reported as means $\pm \mathrm{SD} ; n=3$.

The remaining treatments made differences in the $R_{\mathrm{W}}$ and $R_{\text {aw }}$ of limestone and dolostone in comparison to the control treatment (Table 2), but the differences were much smaller than the treatments with those five fertilizers as mentioned above (Fig. 3). In the $\left(\mathrm{NH}_{4}\right)_{3} \mathrm{PO}_{4}$ treatment, the $R_{\mathrm{w}}$ were only $1.08 \pm 0.34 \%$ and $0.75 \pm 0.21 \%$ o for limestone and dolomite, respectively, while the $R_{\text {aw }}$ were $4.00 \pm 1.15$ and $1.00 \pm 1.01 \mathrm{~g} \mathrm{~m}^{-2} \mathrm{a}^{-1}$ for limestone and dolomite, respectively. The $R_{\mathrm{w}}$ and $R_{\mathrm{aw}}$ in the $\mathrm{NaNO}_{3}$ treatments showed differences with the control treatment. The values, however, are much less than those under the five $\mathrm{NH}_{4}$-based fertilizers mentioned above, exhibiting little effect of the $\mathrm{NaNO}_{3}$ fertilizer addition on carbonate weathering (see Table 2 and Fig. 3). Except for the $R_{\mathrm{w}}$ of limestone approaching 0 in the $\mathrm{Ca}_{3}\left(\mathrm{PO}_{4}\right)_{2}$ treatment, all the values of $R_{\mathrm{w}}$ and $R_{\mathrm{aw}}$ in $\mathrm{Ca}-$ $\mathrm{Mg}-\mathrm{P}, \mathrm{K}_{2} \mathrm{CO}_{3}$ and $\mathrm{Ca}_{3}\left(\mathrm{PO}_{4}\right)_{2}$ treatments showed negative values. This indicates that the addition of $\mathrm{Ca}-\mathrm{Mg}-\mathrm{P}, \mathrm{K}_{2} \mathrm{CO}_{3}$ and $\mathrm{Ca}_{3}\left(\mathrm{PO}_{4}\right)_{2}$ fertilizers led to precipitation at the surface of the carbonate mineral.

\subsection{Comparison of limestone of dolomite}

Figure 3 shows that, on the whole, the ratios of dolostone weathering are smaller than those of limestone weathering except for the $\left(\mathrm{NH}_{4}\right)_{2} \mathrm{CO}_{3}$ treatment, demonstrating that dolostone weathers more slowly than limestone under fertilization effects.

In Fig. 4, we plotted the $R_{\mathrm{w}}$ of limestone vs. dolostone tablets in a linear correlation diagram, in order to compare the weathering responses of limestone with dolostone. The results show that the $R_{\mathrm{W}}$ of limestone and dolostone exhibit a high positive correlation $\left(R^{2}=0.9773\right.$; see Fig. 4), indicating that the weathering of limestone and dolostone are similar under different treatments. Thus, we will explain the re-

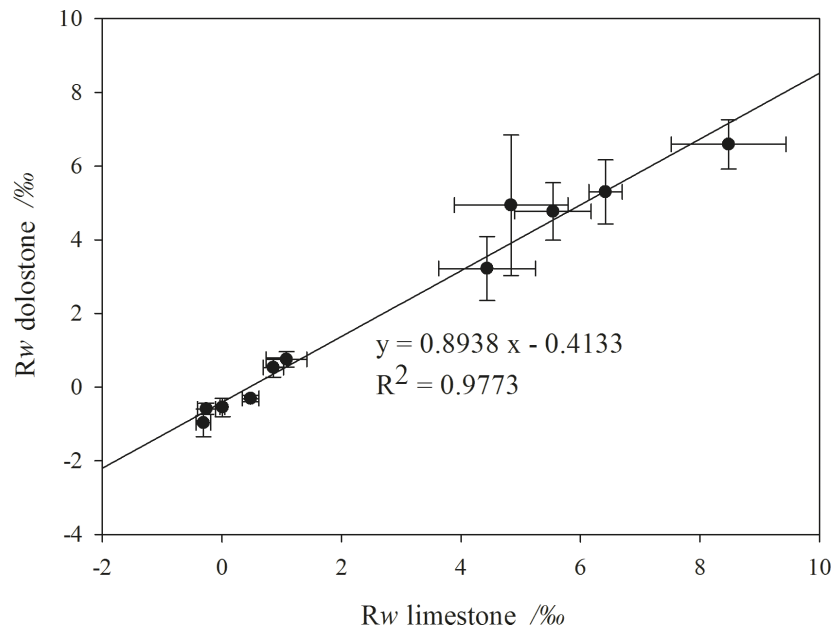

Figure 4. The linear correlation of $R_{\mathrm{W}}(\% \circ)$ of limestone and dolostone. $R_{\mathrm{W}}=1000\left(W_{\mathrm{i}}-W_{\mathrm{f}}\right) / W_{\mathrm{i}}$, where $W_{\mathrm{i}}$ is the initial weight of the limestone tablet and $W_{\mathrm{f}}$ is the final weight.

sults in terms of carbonates, rather than separately discussing the individual dolostone and limestone.

\section{Discussion}

\subsection{Kinetics of carbonate dissolution/precipitation: controlling factors}

Experimental studies of carbonate dissolution kinetics have shown that metal carbonate weathering usually depends upon three parallel reactions occurring at the carbonate interface (Chou et al., 1989; Plummer et al., 1978; Pokrovsky et al., 
2009):

$\mathrm{MeCO}_{3} \leftrightarrow \mathrm{Me}^{2+}+\mathrm{CO}_{3}^{2-}$,

$\mathrm{MeCO}_{3}+\mathrm{H}_{2} \mathrm{CO}_{3} \leftrightarrow \mathrm{Me}^{2+}+2 \mathrm{HCO}_{3}^{-}$,

$\mathrm{MeCO}_{3}+\mathrm{H}^{+} \leftrightarrow \mathrm{Me}^{2+}+\mathrm{HCO}_{3}^{-}$,

where $\mathrm{Me}=\mathrm{Ca}, \mathrm{Mg}$. As Eq. (5) describes, atmospheric/soil $\mathrm{CO}_{2}$ is usually considered to be the natural weathering agent of carbonate. In watersheds with calcite- and dolomitecontaining bedrock, $\mathrm{H}_{2} \mathrm{CO}_{3}$ formed in the soil zone usually reacts with carbonate minerals, resulting in dissolved $\mathrm{Ca}, \mathrm{Mg}$ and $\mathrm{HCO}_{3}^{-}$as described in Eq. (5) (Andrews and Schlesinger, 2001; Shin et al., 2014). Although it has been proven that the reaction of carbonate dissolution is mainly controlled by the amount of rainfall (Amiotte Suchet et al., 2003; Egli and Fitze, 2001; Kiefer, 1994), in this study, we consider that the effect of rainfall is equal in each soil column, and hence it is disregarded as a controlling factor in weathering rate differences among these treatments. In theory, the fertilizers could stimulate bacteria, which may increase respiration and $\mathrm{CO}_{2}$ concentrations in the soil, and, as a result, probably enhance carbonate weathering as Eq. (5). However, Eq. (6) suggests that the proton from other origins, such as the nitrification processes of $\mathrm{NH}_{4}^{+}$, as mentioned in the Introduction section, can play the role of weathering agent in agricultural areas. In this study, the urea, $\mathrm{NH}_{4} \mathrm{NO}_{3}, \mathrm{NH}_{4} \mathrm{HCO}_{3}, \mathrm{NH}_{4} \mathrm{Cl}$ and $\left(\mathrm{NH}_{4}\right)_{2} \mathrm{CO}_{3}$ amendments increased (10- to 17-fold) the natural weathering rate from $2.00 \mathrm{~g} \mathrm{~m}^{-2} \mathrm{a}^{-1}$ for limestone tablets in the control treatment (Table 2). Thus, these increases are strongly related to the effect of proton release from the nitrification of $\mathrm{NH}_{4}^{+}$. In contrast, carbonate precipitation will occur due to the backward reaction of Eq. (5) in the following cases: (1) the degassing of dissolved $\mathrm{CO}_{2}$ due to dramatic changes in the parameters of the $\mathrm{CO}_{2}$ system (such as $T, \mathrm{pH}$ and $p \mathrm{CO}_{2}$ ); (2) soil evapotranspiration; or (3) the common ion effect: the increase in $\mathrm{Ca}^{2+}, \mathrm{Mg}^{2+}$ or $\mathrm{CO}_{3}^{2-}$ in a weathering system with equilibrium between water and calcite (Calmels et al., 2014; Dreybrodt, 1998).

\subsection{Main reactions and effects in different treatments}

The main reactions and effects of every treatment in this study are listed in Table 3.

\subsubsection{Nitrification in $\mathrm{NH}_{4}$ fertilizer: $\mathrm{NH}_{4} \mathrm{NO}_{3}$, $\mathrm{NH}_{4} \mathrm{HCO}_{3}, \mathrm{NH}_{4} \mathrm{Cl},\left(\mathrm{NH}_{4}\right)_{2} \mathrm{CO}_{3}$ and urea}

In urea $\left(\mathrm{CO}\left(\mathrm{NH}_{2}\right)_{2}\right)$ treatment, the enzyme urease rapidly hydrolyzes the urea $\mathrm{N}$ to $\mathrm{NH}_{4}^{+}$ions (Eq. 7) when urea is applied to the soil (Soares et al., 2012).

$\mathrm{CO}\left(\mathrm{NH}_{2}\right)_{2}+3 \mathrm{H}_{2} \mathrm{O} \rightarrow 2 \mathrm{NH}_{4}^{+}+2 \mathrm{OH}^{-}+\mathrm{CO}_{2}$

Although the study of Singh et al. (2013) showed that part of $\mathrm{NH}_{4}^{+}$may be lost as ammonia $\left(\mathrm{NH}_{3}\right)$ and subsequently as nitrous oxide $\left(\mathrm{N}_{2} \mathrm{O}\right)$ (Singh et al., 2013), the remaining ammonium $\left(\mathrm{NH}_{4}^{+}\right)$is mainly oxidized during nitrification in soil by autotrophic bacteria, such as Nitrosomonas, resulting in nitrite $\mathrm{NO}_{2}^{-}$and $\mathrm{H}^{+}$ions. Nitrite is in turn oxidized by another bacterium, such as Nitrobacter, resulting in nitrate $\left(\mathrm{NO}_{3}^{-}\right)$(Eq. 8) (Perrin et al., 2008).

$\mathrm{NH}_{4}^{+}+2 \mathrm{O}_{2} \rightarrow \mathrm{NO}_{3}^{-}+\mathrm{H}_{2} \mathrm{O}+2 \mathrm{H}^{+}$

The protons $\left(\mathrm{H}^{+}\right)$produced by nitrification can be neutralized in two ways: (i) either by the exchange process with base cations in the soil exchange complex (Eq. 9),

Soil $-\mathrm{Ca}+2 \mathrm{H}^{+} \rightarrow$ Soil $-2 \mathrm{H}^{+}+\mathrm{Ca}^{2+}$,

or (ii) via carbonate mineral dissolution (Eq. 10):

$$
\begin{aligned}
& \mathrm{Ca}_{(1-x)} \mathrm{Mg}_{x} \mathrm{CO}_{3}+\mathrm{H}^{+} \rightarrow(1-x) \mathrm{Ca}^{2+} \\
& +x \mathrm{Mg}^{2+}+\mathrm{HCO}_{3}^{-} .
\end{aligned}
$$

Consequently, by combining Eqs. (8) and (10), carbonate weathering by protons produced by nitrification can be expressed as (Eq. 11) (see details in Perrin et al., 2008 and Gandois et al., 2011).

$$
\begin{aligned}
& 2 \mathrm{Ca}_{(1-x)} \mathrm{Mg}_{x} \mathrm{CO}_{3}+\mathrm{NH}_{4}^{+}+2 \mathrm{O}_{2} \rightarrow 2(1-x) \mathrm{Ca}^{2+} \\
& +2 x \mathrm{Mg}^{2+}+\mathrm{NO}_{3}^{-}+\mathrm{H}_{2} \mathrm{O}+2 \mathrm{HCO}_{3}^{-}
\end{aligned}
$$

As discussed above, provided that the loss as ammonia $\left(\mathrm{NH}_{3}\right)$ and nitrous oxide $\left(\mathrm{N}_{2} \mathrm{O}\right)$ after hydrolysis is disregarded in this study, the final equation of carbonate weathering in the $\mathrm{NH}_{4} \mathrm{NO}_{3}, \mathrm{NH}_{4} \mathrm{HCO}_{3}, \mathrm{NH}_{4} \mathrm{Cl},\left(\mathrm{NH}_{4}\right)_{2} \mathrm{CO}_{3}$ and urea treatments will be as follows, respectively:

$$
\begin{aligned}
& 2 \mathrm{Ca}_{(1-x)} \mathrm{Mg}_{x} \mathrm{CO}_{3}+\mathrm{NH}_{4} \mathrm{NO}_{3}+2 \mathrm{O}_{2} \rightarrow 2(1-x) \mathrm{Ca}^{2+} \\
& +2 x \mathrm{Mg}^{2+}+2 \mathrm{NO}_{3}^{-}+\mathrm{H}_{2} \mathrm{O}+2 \mathrm{HCO}_{3}^{-}, \\
& 2 \mathrm{Ca}_{(1-x)} \mathrm{Mg}_{x} \mathrm{CO}_{3}+\mathrm{NH}_{4} \mathrm{HCO}_{3}+2 \mathrm{O}_{2} \rightarrow 2(1-x) \mathrm{Ca}^{2+} \\
& +2 x \mathrm{Mg}^{2+}+\mathrm{NO}_{3}^{-}+\mathrm{H}_{2} \mathrm{O}+3 \mathrm{HCO}_{3}^{-}, \\
& 2 \mathrm{Ca}_{(1-x)} \mathrm{Mg}_{x} \mathrm{CO}_{3}+\mathrm{NH}_{4} \mathrm{Cl}+2 \mathrm{O}_{2} \rightarrow 2(1-x) \mathrm{Ca}^{2+} \\
& +2 x \mathrm{Mg}^{2+}+\mathrm{NO}_{3}^{-}+\mathrm{Cl}^{-}+\mathrm{H}_{2} \mathrm{O}+2 \mathrm{HCO}_{3}^{-}, \\
& 3 \mathrm{Ca}_{(1-x)} \mathrm{Mg}_{x} \mathrm{CO}_{3}+\left(\mathrm{NH}_{4}\right)_{2} \mathrm{CO}_{3}+4 \mathrm{O}_{2} \rightarrow 3(1-x) \mathrm{Ca}^{2+} \\
& +3 x \mathrm{Mg}^{2+}+2 \mathrm{NO}_{3}^{-}+2 \mathrm{H}_{2} \mathrm{O}+4 \mathrm{HCO}_{3}^{-}, \\
& 3 \mathrm{Ca}_{(1-x)} \mathrm{Mg}_{x} \mathrm{CO}_{3}+\mathrm{CO}\left(\mathrm{NH}_{2}\right)_{2}+4 \mathrm{O}_{2} \\
& \rightarrow 3(1-x) \mathrm{Ca}^{2+}+3 x \mathrm{Mg}^{2+}+2 \mathrm{NO}_{3}^{-}+4 \mathrm{HCO}_{3}^{-} .
\end{aligned}
$$

\subsubsection{No effect of $\mathrm{NO}_{3}$ fertilizer treatment: $\mathrm{NaNO}_{3}$ treatment}

In the $\mathrm{NaNO}_{3}$ treatment, the reaction occurs according to Eq. (17), indicating that the addition of $\mathrm{NO}_{3}$ fertilizer does not significantly influence carbonate weathering.

$$
\begin{aligned}
& \mathrm{Ca}_{(1-x)} \mathrm{Mg}_{x} \mathrm{CO}_{3}+\mathrm{NaNO}_{3}+\mathrm{CO}_{2}+\mathrm{H}_{2} \mathrm{O} \\
& \rightarrow(1-x) \mathrm{Ca}^{2+}+x \mathrm{Mg}^{2+}+\mathrm{Na}^{+}+\mathrm{NO}_{3}^{-}+2 \mathrm{HCO}_{3}^{-}
\end{aligned}
$$


Table 3. The main reaction and effects in the 11 fertilizer treatments.

\begin{tabular}{|c|c|}
\hline Treatment & Main reactions and effects \\
\hline 1. Control & $\mathrm{Ca}_{(1-x)} \mathrm{Mg}_{x} \mathrm{CO}_{3}+\mathrm{CO}_{2}+\mathrm{H}_{2} \mathrm{O} \rightarrow(1-x) \mathrm{Ca}^{2+}+x \mathrm{Mg}^{2+}+2 \mathrm{HCO}_{3}^{-}$ \\
\hline 2. $\mathrm{NH}_{4} \mathrm{NO}_{3}$ & $2 \mathrm{Ca}(1-x) \mathrm{Mg}_{x} \mathrm{CO}_{3}+\mathrm{NH}_{4} \mathrm{NO}_{3}+2 \mathrm{O}_{2} \rightarrow 2(1-x) \mathrm{Ca}^{2+}+2 x \mathrm{Mg}^{2+}+2 \mathrm{NO}_{3}^{-}+\mathrm{H}_{2} \mathrm{O}+2 \mathrm{HCO}_{3}^{-}$ \\
\hline 3. $\mathrm{NH}_{4} \mathrm{HCO}_{3}$ & $\mathrm{NH}_{4} \mathrm{HCO}_{3} \rightarrow \mathrm{NH}_{3} \uparrow+\mathrm{H}_{2} \mathrm{O}+\mathrm{CO}_{2} \uparrow$ \\
\hline & $2 \mathrm{Ca}_{(1-x)} \mathrm{Mg}_{x} \mathrm{CO}_{3}+\mathrm{NH}_{4} \mathrm{HCO}_{3}+2 \mathrm{O}_{2} \rightarrow 2(1-\mathrm{x}) \mathrm{Ca}^{2+}+2 x \mathrm{Mg}^{2+}+\mathrm{NO}_{3}^{-}+\mathrm{H}_{2} \mathrm{O}+3 \mathrm{HCO}_{3}^{-}$ \\
\hline 4. $\mathrm{NaNO}_{3}$ & $\mathrm{Ca}_{(1-x)} \mathrm{Mg}_{x} \mathrm{CO}_{3}+\mathrm{NaNO}_{3}+\mathrm{CO}_{2}+\mathrm{H}_{2} \mathrm{O} \rightarrow(1-x) \mathrm{Ca}^{2+}+x \mathrm{Mg}^{2+}+\mathrm{Na}^{+}+\mathrm{NO}_{3}^{-}+2 \mathrm{HCO}_{3}^{-}$ \\
\hline $\begin{array}{l}\text { 5. } \mathrm{NH}_{4} \mathrm{Cl} \\
\text { 6. }\left(\mathrm{NH}_{4}\right)_{2} \mathrm{CO}_{3}\end{array}$ & $\begin{array}{l}2 \mathrm{Ca}(1-x) \mathrm{Mg}_{x} \mathrm{CO}_{3}+\mathrm{NH}_{4} \mathrm{Cl}+2 \mathrm{O}_{2} \rightarrow 2(1-x) \mathrm{Ca}^{2+}+2 x \mathrm{Mg}^{2+}+\mathrm{NO}_{3}^{-}+\mathrm{Cl}^{-}+\mathrm{H}_{2} \mathrm{O}+2 \mathrm{HCO}_{3}^{-} \\
\left(\mathrm{NH}_{4}\right)_{2} \mathrm{CO}_{3} \rightarrow 2 \mathrm{NH}_{3} \uparrow+\mathrm{H}_{2} \mathrm{O}+\mathrm{CO}_{2} \uparrow\end{array}$ \\
\hline 7. $\mathrm{Ca}_{3}\left(\mathrm{PO}_{4}\right)_{2}$ & $\begin{array}{l}3 \mathrm{Ca}_{(1-x)} \mathrm{Mg}_{x} \mathrm{CO}_{3}+\left(\mathrm{NH}_{4}\right)_{2} \mathrm{CO}_{3}+4 \mathrm{O}_{2} \rightarrow 3(1-x) \mathrm{Ca}^{2+}+3 x \mathrm{Mg}^{2+}+2 \mathrm{NO}_{3}^{-}+2 \mathrm{H}_{2} \mathrm{O}+4 \mathrm{HCO}_{3}^{-} \\
\text {(1) }(1-x) \mathrm{Ca}^{2+}+x \mathrm{Mg}^{2+}+2 \mathrm{HCO}_{3}^{-} \rightarrow \mathrm{Ca}_{(1-x)} \mathrm{Mg}_{x} \mathrm{CO}_{3}+\mathrm{CO}_{2}+\mathrm{H}_{2} \mathrm{O} \\
\text { (2) } \mathrm{Ca}+\mathrm{PO}_{4} \rightarrow \mathrm{Ca}-\mathrm{P}\end{array}$ \\
\hline 8. $\left(\mathrm{NH}_{4}\right)_{3} \mathrm{PO}_{4}$ & $\begin{array}{l}\text { (1) } 2 \mathrm{Ca}_{(1-x)} \mathrm{Mg}_{x} \mathrm{CO}_{3}+\mathrm{NH}_{4}^{+}+2 \mathrm{O}_{2} \rightarrow 2(1-x) \mathrm{Ca}^{2+}+2 x \mathrm{Mg}^{2+}+\mathrm{NO}_{3}^{-}+\mathrm{H}_{2} \mathrm{O}+2 \mathrm{HCO}_{3}^{-} \\
\text {(2) } \mathrm{Ca}+\mathrm{PO}_{4} \rightarrow \mathrm{Ca}-\mathrm{P}\end{array}$ \\
\hline 9. $\mathrm{Ca}-\mathrm{Mg}-\mathrm{P}$ & $\begin{array}{l}\text { (1) }(1-x) \mathrm{Ca}^{2+}+x \mathrm{Mg}^{2+}+2 \mathrm{HCO}_{3}^{-} \rightarrow \mathrm{Ca}(1-x) \mathrm{Mg}_{x} \mathrm{CO}_{3}+\mathrm{CO}_{2}+\mathrm{H}_{2} \mathrm{O} \\
\text { (2) } \mathrm{Ca}+\mathrm{PO}_{4} \rightarrow \mathrm{Ca}-\mathrm{P}\end{array}$ \\
\hline $\begin{array}{l}\text { 10. Urea } \\
\text { 11. } \mathrm{K}_{2} \mathrm{CO}_{3}\end{array}$ & $\begin{array}{l}3 \mathrm{Ca}_{(1-x)} \mathrm{Mg}_{x} \mathrm{CO}_{3}+\mathrm{CO}\left(\mathrm{NH}_{2}\right)_{2}+4 \mathrm{O}_{2} \rightarrow 3(1-x) \mathrm{Ca}^{2+}+3 x \mathrm{Mg}^{2+}+2 \mathrm{NO}_{3}^{-}+4 \mathrm{HCO}_{3}^{-} \\
\text {(i) }(1-x) \mathrm{Ca}^{2+}+x \mathrm{Mg}^{2+}+2 \mathrm{HCO}_{3}^{-} \rightarrow \mathrm{Ca}_{(1-x)} \mathrm{Mg}_{x} \mathrm{CO}_{3}+\mathrm{CO}_{2}+\mathrm{H}_{2} \mathrm{O} \\
\text { (ii) } \mathrm{K}_{2} \mathrm{CO}_{3}+\mathrm{H}_{2} \mathrm{O} \rightarrow 2 \mathrm{~K}^{+}+\mathrm{HCO}_{3}^{-}+\mathrm{OH}^{-}\end{array}$ \\
\hline
\end{tabular}

(1) Common ion effect: the $\mathrm{Ca}_{(1-x)} \mathrm{Mg}_{x} \mathrm{CO}_{3}$ produced when the concentrations of $\mathrm{Ca}^{2+}, \mathrm{Mg}^{2+}$ and/or $\mathrm{HCO}_{3}^{-}$increase (for treatments 7, 9 and 11): $(1-x) \mathrm{Ca}^{2+}+x \mathrm{Mg}^{2+}+2 \mathrm{HCO}_{3}^{-} \rightarrow \mathrm{Ca}_{(1-x)} \mathrm{Mg}_{x} \mathrm{CO}_{3}+\mathrm{CO}_{2}+\mathrm{H}_{2} \mathrm{O}$; (2) Inhibition of calcite dissolution/precipitation by phosphate: calcium orthophosphate ( $\mathrm{Ca}-\mathrm{P})$ precipitation produced on the surface of calcite after the addition of $\mathrm{PO}_{4}^{3-}$ in soil, resulting in the inhibition of the dissolution/precipitation of calcite (for treatments 7, 8 and 9): $\mathrm{Ca}+\mathrm{PO}_{4} \rightarrow \mathrm{Ca}-\mathrm{P}$.

\subsubsection{Common ion effect: $\mathrm{K}_{2} \mathrm{CO}_{3}$ treatment}

In the $\mathrm{K}_{2} \mathrm{CO}_{3}$ treatment, $\mathrm{CO}_{3}^{2-}$ and $\mathrm{HCO}_{3}^{-}$will be produced after the addition of $\mathrm{K}_{2} \mathrm{CO}_{3}$ according to Eq. (18), hence resulting in carbonate precipitation as described in Eq. (19), due to the common ion effect.

$$
\begin{aligned}
& \mathrm{K}_{2} \mathrm{CO}_{3}+\mathrm{H}_{2} \mathrm{O} \rightarrow 2 \mathrm{~K}^{+}+\mathrm{HCO}_{3}^{-}+\mathrm{OH}^{-} \\
& (1-x) \mathrm{Ca}^{2+}+x \mathrm{Mg}^{2+}+2 \mathrm{HCO}_{3}^{-} \rightarrow \mathrm{Ca}_{(1-x)} \mathrm{Mg}_{x} \mathrm{CO}_{3} \\
& +\mathrm{CO}_{2}+\mathrm{H}_{2} \mathrm{O}
\end{aligned}
$$

\subsubsection{Complex effects: nitrification vs. the inhibition effect of $\mathrm{PO}_{4}$ in $\left(\mathrm{NH}_{4}\right)_{3} \mathrm{PO}_{4}$ treatments}

In the $\left(\mathrm{NH}_{4}\right)_{3} \mathrm{PO}_{4}$ treatment, the reaction of carbonate weathering will occur according to Eq. (11) due to the nitrification of $\mathrm{NH}_{4}^{+}$ionized from the $\left(\mathrm{NH}_{4}\right)_{3} \mathrm{PO}_{4}$ fertilizer. The $\mathrm{PO}_{4}^{3-}$ anion will exert an inhibition to calcite dissolution (Kitano et al., 1978), as calcium orthophosphate (Ca-P) precipitation is produced on the surface of calcite after the addition of $\mathrm{PO}_{4}^{3-}$ in soil (reaction: $\mathrm{Ca}+\mathrm{PO}_{4} \rightarrow \mathrm{Ca}-\mathrm{P}$ ), resulting in the inhibition of the calcite dissolution (Alkattan et al., 2002; Berner and Morse, 1974; Raistrick, 1949).

\subsubsection{Complex effects: common ion effect vs. the inhibition effect of $\mathrm{PO}_{4}$ in $\mathrm{Ca}_{3}\left(\mathrm{PO}_{4}\right)_{2}$ and $\mathrm{Ca}-\mathrm{Mg}-\mathrm{P}$ treatments}

In the $\mathrm{Ca}_{3}\left(\mathrm{PO}_{4}\right)_{2}$ and $\mathrm{Ca}-\mathrm{Mg}-\mathrm{P}$ treatments, on the one hand, $\mathrm{Ca}_{(1-x)} \mathrm{Mg}_{x} \mathrm{CO}_{3}$ is produced when the concentrations of
$\mathrm{Ca}^{2+}$ (and/or $\mathrm{Mg}^{2+}$ ) increase according to Eq. (19). On the other hand, the inhibition effect of phosphate will cause calcium phosphate precipitation to be produced on the surface of carbonate minerals after the addition of $\mathrm{P}$ in soil (reaction: $\left.\mathrm{Ca}+\mathrm{PO}_{4} \rightarrow \mathrm{Ca}-\mathrm{P}\right)$, resulting in the inhibition of the carbonate precipitation (Alkattan et al., 2002; Burton and Walter, 1990; Giannimaras and Koutsoukos, 1987; House, 1987; Ishikawa and Ichikuni, 1981; Lin and Singer, 2006; Mucci, 1986; Reddy, 1977).

\subsection{Difference between $\mathrm{NH}_{4}^{+}$and $\mathrm{NO}_{3}^{-}$in impacts on carbonate weathering and implication of the estimation of $\mathrm{CO}_{2}$ consumption}

In order to further compare the differences between $\mathrm{NH}_{4}^{+}$ and $\mathrm{NO}_{3}^{-}$effects on carbonate weathering, the initial molar amounts of fertilizer-derived $\mathrm{NH}_{4}$ unit ${ }^{-1}$ in every treatment were calculated and are listed in Table 4 . The results show that the amount of $\mathrm{NH}_{4}^{+}$hydrolyzed from added urea is 1.06 mole, while $\mathrm{NH}_{4}^{+}$ionized from added $\mathrm{NH}_{4} \mathrm{NO}_{3}, \mathrm{NH}_{4} \mathrm{HCO}_{3}$, $\mathrm{NH}_{4} \mathrm{Cl},\left(\mathrm{NH}_{4}\right)_{2} \mathrm{CO}_{3}$ and $\left(\mathrm{NH}_{4}\right)_{3} \mathrm{PO}_{4}$ is $0.54,1.08,1.07$, 1.06 and 0.03 mole, respectively (Table 4 ). The $R_{\mathrm{w}}$ of limestone tablets and the initial amount of $\mathrm{NH}_{4}^{+}$treatment ${ }^{-1}$ are plotted in Fig. 5. A distinct relationship between them is observed, in that the $R_{\mathrm{w}}$ values in $\mathrm{NH}_{4} \mathrm{NO}_{3}, \mathrm{NH}_{4} \mathrm{HCO}_{3}$, $\mathrm{NH}_{4} \mathrm{Cl},\left(\mathrm{NH}_{4}\right)_{2} \mathrm{CO}_{3}$ and urea treatments are larger than in the control treatment, where the initial amount of $\mathrm{NH}_{4}^{+}$yields similar results (Fig. 5). This suggests that carbonate weathering in $\mathrm{NH}_{4} \mathrm{NO}_{3}, \mathrm{NH}_{4} \mathrm{HCO}_{3}, \mathrm{NH}_{4} \mathrm{Cl},\left(\mathrm{NH}_{4}\right)_{2} \mathrm{CO}_{3}$ and urea 
treatments are mainly attributed to the dissolution reaction described as Eq. (11). This process of carbonate weathering by protons released from nitrification has been demonstrated by many studies, from the laboratory to the field (Barnes and Raymond, 2009; Bertrand et al., 2007; Biasi et al., 2008; Errin et al., 2006; Gandois et al., 2011; Hamilton et al., 2007; Oh and Raymond, 2006; Perrin et al., 2008; Semhi and Suchet, 2000; Song et al., 2017a, 2011; West and McBride, 2005). We have noted that the $R_{\mathrm{w}}$ values in $\mathrm{NH}_{4} \mathrm{HCO}_{3}$ and $\left(\mathrm{NH}_{4}\right)_{2} \mathrm{CO}_{3}$ treatments are less than half those in the urea treatment despite adding the same amount of fertilizerderived $\mathrm{NH}_{4}$ (approximately 1.07 mole). This is probably because the two fertilizers, $\mathrm{NH}_{4} \mathrm{HCO}_{3}$ and $\left(\mathrm{NH}_{4}\right)_{2} \mathrm{CO}_{3}$ as a typical weak acid and weak base salt, are easier to decompose and produce $\mathrm{NH}_{3}$ and $\mathrm{CO}_{2}$ gases according to Eqs. (20) and (21) (Trypuc and Kielkowska, 1996), resulting in amounts of fertilizer-derived $\mathrm{NH}_{4}$ that are lower than 1.07 moles.

$$
\begin{aligned}
& \mathrm{NH}_{4} \mathrm{HCO}_{3} \rightarrow \mathrm{NH}_{3} \uparrow+\mathrm{H}_{2} \mathrm{O}+\mathrm{CO}_{2} \uparrow \\
& \left(\mathrm{NH}_{4}\right)_{2} \mathrm{CO}_{3} \rightarrow 2 \mathrm{NH}_{3} \uparrow+\mathrm{H}_{2} \mathrm{O}+\mathrm{CO}_{2} \uparrow
\end{aligned}
$$

The $A_{\mathrm{W}}$ and $R_{\mathrm{W}}$ in the $\left(\mathrm{NH}_{4}\right)_{3} \mathrm{PO}_{4}$ treatment, unlike in other $\mathrm{NH}_{4}$ fertilizer treatments, do not show a significant increase compared to the control treatment, which is not only owing to the low amount of added $\mathrm{NH}_{4}^{+}$in the $\left(\mathrm{NH}_{4}\right)_{3} \mathrm{PO}_{4}$ treatment ( 0.3 mole; see Table 4$)$ but also to the inhibition of phosphate (Chien et al., 2011; Wang et al., 2012). After the addition of $\left(\mathrm{NH}_{4}\right)_{3} \mathrm{PO}_{4}$ in soil, calcium orthophosphate $(\mathrm{Ca}-$ $\mathrm{P})$ precipitation will form on calcite surfaces, which is initiated with the aggregation of clusters leading to the nucleation and subsequent growth of $\mathrm{Ca}-\mathrm{P}$ phases, at various $\mathrm{pH}$ values and ionic strengths relevant to soil solution conditions (Chien et al., 2011; Wang et al., 2012).

There is no significant different between the $R_{\mathrm{W}}$ in the $\mathrm{NaNO}_{3}$ treatment compared to the control treatment, indicating that the addition of $\mathrm{NO}_{3}$ fertilizer does not significantly influence carbonate weathering.

A notable issue herein is that the $\mathrm{NaNO}_{3}$ treatment produces the same amount of $\mathrm{NO}_{3}^{-}(1.07$ mole $)$ as other $\mathrm{NH}_{4}$ fertilizer $\left(\mathrm{NH}_{4} \mathrm{NO}_{3}, \mathrm{NH}_{4} \mathrm{HCO}_{3}, \mathrm{NH}_{4} \mathrm{Cl},\left(\mathrm{NH}_{4}\right)_{2} \mathrm{CO}_{3}\right.$ and urea), but it fails to impact carbonate weathering, which raises a new problem. Equation (5), usually considered as an expression for the natural weathering process of carbonate, is an important reaction in understanding the kinetics of carbonate dissolution in carbonate-dominated areas, where the molar ratio of $\mathrm{HCO}_{3}^{-}$and $\mathrm{Me}^{2+}$ in the river is usually used as an indicator to make estimates of $\mathrm{CO}_{2}$ consumption by carbonate weathering on the regional/global scale (Hagedorn and Cartwright, 2009; Li et al., 2009). In agricultural areas, the relationship between $(\mathrm{Ca}+\mathrm{Mg}) / \mathrm{HCO}_{3}^{-}$and $\mathrm{NO}_{3}^{-}$is usually employed to estimate the contribution of $\mathrm{N}$ fertilizer to riverine $\mathrm{Ca}^{2+}, \mathrm{Mg}^{2+}$ and alkalinity (Etchanchu and Probst, 1988; Jiang, 2013; Jiang et al., 2009; Perrin et al., 2008; Semhi and Suchet, 2000). In these studies, the nitrification

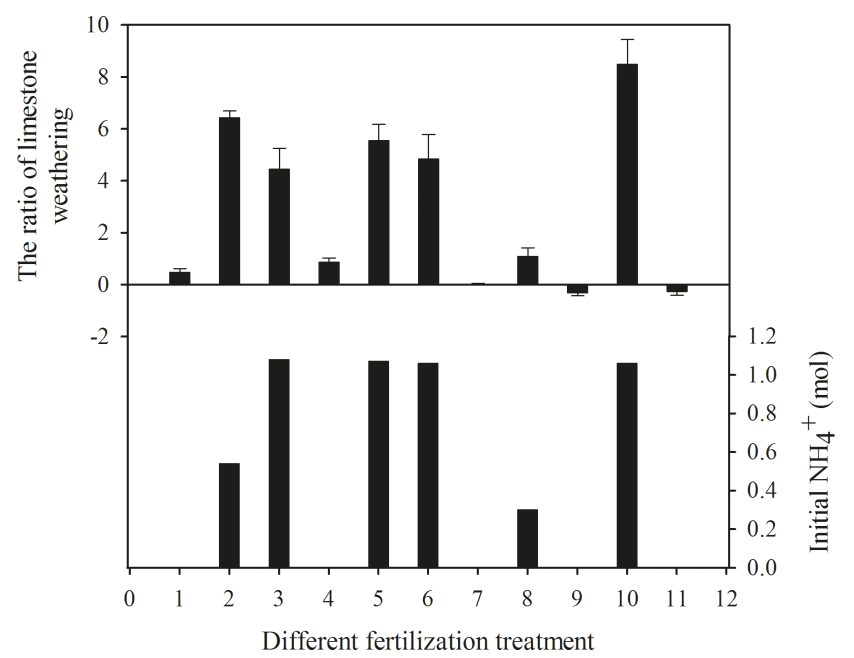

Figure 5. The $R_{\mathrm{W}}(\% o)$ of limestone and the molar amount of produced $\mathrm{NH}_{4}^{+}$under different fertilizer treatments: 1 - control; $2-\mathrm{NH}_{4} \mathrm{NO}_{3} ; 3-\mathrm{NH}_{4} \mathrm{HCO}_{3} ; 4-\mathrm{NaNO}_{3} ; 5-\mathrm{NH}_{4} \mathrm{Cl} ; 6-$ $\left(\mathrm{NH}_{4}\right)_{2} \mathrm{CO}_{3} ; 7-\mathrm{Ca}_{3}\left(\mathrm{PO}_{4}\right)_{2} ; 8-\left(\mathrm{NH}_{4}\right)_{3} \mathrm{PO}_{4} ; 9-\mathrm{Ca}-\mathrm{Mg}-\mathrm{P} ; 10$ - urea; $11-\mathrm{K}_{2} \mathrm{CO}_{3} . R_{\mathrm{W}}=1000\left(W_{\mathrm{i}}-W_{\mathrm{f}}\right) / W_{\mathrm{i}}$, where $W_{\mathrm{i}}$ is the initial weight of the limestone tablet and $W_{\mathrm{f}}$ is the final weight.

described in Eq. (8) is usually considered as the unique origin of $\mathrm{NO}_{3}^{-}$. According to the results of the $\mathrm{NaNO}_{3}$ treatment in this study, the contribution of protons from nitrification to carbonate weathering may be overestimated if anthropogenic $\mathrm{NO}_{3}^{-}$is neglected, since the anthropogenic $\mathrm{NO}_{3}^{-}$does not release the proton described in Eq. (8). For $\mathrm{NH}_{4} \mathrm{NO}_{3}$ fertilizer, Eq. (12) shows that two moles of $\mathrm{Ca}^{2+}+\mathrm{Mg}^{2+}, \mathrm{NO}_{3}^{-}$and $\mathrm{HCO}_{3}^{-}$will be produced when 1 mole $\mathrm{NH}_{4} \mathrm{NO}_{3}$ reacts with 2 moles of carbonate, where only half of the $\mathrm{NO}_{3}^{-}$originates from nitrification described as Eq. (8). This will result in an overestimation of the contribution of nitrification to carbonate weathering and thus thereby falsify the estimation of $\mathrm{CO}_{2}$ consumption.

On regional scales, if different fertilizers are simultaneously added to an agricultural area, the estimation of $\mathrm{CO}_{2}$ consumption by carbonate weathering might become more complicated, since the mole ratios of $\mathrm{Ca}+\mathrm{Mg}, \mathrm{HCO}_{3}^{-}$and/or $\mathrm{NO}_{3}^{-}$between different fertilization treatments are different (see Table 3). Thus, the related anthropogenic inputs (e.g., $\mathrm{Ca}+\mathrm{Mg}, \mathrm{NH}_{4}, \mathrm{NO}_{3}^{-}$and $\mathrm{HCO}_{3}^{-}$) need to be investigated to more accurately estimate the impact of fertilization on carbonate weathering and its $\mathrm{CO}_{2}$ consumption.

\subsection{The comparison with other studied results}

The $R_{\mathrm{W}}$ and $R_{\mathrm{aw}}$ of limestone in the control treatment in this study were $0.48 \%$ and $2.00 \mathrm{~g} \mathrm{~m}^{-2} \mathrm{a}^{-1}$, respectively. These are generally consistent with observations of $0.51-$ $32.97 \mathrm{~g} \mathrm{~m}^{-2} \mathrm{a}^{-1}$ (for $R_{\text {aw }}$ ) in Nongla, Guangxi, a karst area of Southwestern China (Zhang, 2011), and with the results of $0.05-5.06 \%$ (for $R_{\mathrm{W}}$ ) and 1.08-136.90 $\mathrm{g} \mathrm{m}^{-2} \mathrm{a}^{-1}$ (for $R_{\mathrm{aw}}$ ) 
Table 4. The amount of fertilizer-derived $\mathrm{NH}_{4}^{+}$in the initial phase of the experiment and the potential nitrogenous transformation $\left(\mathrm{NH}_{4}^{+}-\right.$ $\left.\mathrm{NO}_{3}^{-}\right)$.

\begin{tabular}{|c|c|c|c|c|c|}
\hline Treatment & $\begin{array}{r}\text { Molecular mass } \\
\left(\mathrm{g} \mathrm{mol}^{-1}\right)\end{array}$ & $\begin{array}{r}\text { Amount of added } \\
\text { fertilizer }(\mathrm{g})\end{array}$ & $\begin{array}{r}\text { Molar amount of added } \\
\text { fertilizer (mole) }\end{array}$ & $\begin{array}{l}\text { Amount of fertilizer-derived } \\
\qquad \mathrm{NH}_{4}^{+} \text {(mole) }\end{array}$ & $\begin{array}{l}\text { The maximum of } \\
\mathrm{N} \text { products (mole) }\end{array}$ \\
\hline $\mathrm{NH}_{4} \mathrm{NO}_{3}$ & 80 & 43 & 0.54 & 0.54 & 1.08 \\
\hline $\mathrm{NH}_{4} \mathrm{HCO}_{3}$ & 79 & 85 & 1.08 & 1.08 & 1.08 \\
\hline $\mathrm{NaNO}_{3}$ & 85 & 91 & 1.07 & 0.00 & 1.07 \\
\hline $\mathrm{NH}_{4} \mathrm{Cl}$ & 53.5 & 57 & 1.07 & 1.07 & 1.07 \\
\hline$\left(\mathrm{NH}_{4}\right)_{2} \mathrm{CO}_{3}$ & 96 & 51 & 0.53 & 1.06 & 1.06 \\
\hline $\mathrm{Ca}_{3}\left(\mathrm{PO}_{4}\right)_{2}$ & 310 & 52 & 0.17 & 0.00 & 0.00 \\
\hline$\left(\mathrm{NH}_{4}\right)_{3} \mathrm{PO}_{4}$ & 149 & 15 & 0.10 & 0.30 & 0.30 \\
\hline $\mathrm{Ca}-\mathrm{Mg}-\mathrm{P}$ & nd & 44 & nd & 0.00 & 0.00 \\
\hline Urea & 60 & 32 & 0.53 & 1.06 & 1.06 \\
\hline $\mathrm{K}_{2} \mathrm{CO}_{3}$ & 138 & 10 & 0.07 & 0.00 & 0.00 \\
\hline
\end{tabular}

"nd": no data. The amount of added fertilizer ( $\mathrm{g}$ ) divided by its molecular mass $\left(\mathrm{g} \mathrm{mol}^{-1}\right.$ ) is the molar amount of fertilizer (mole). The amounts of fertilizer-derived NH $4_{4}^{+}$are calculated by their own ionization or hydrolysis processes. The maximum of $\mathrm{N}$ products is estimated by their main reactions in Table 3 .

from the north slope of the Hochschwab Massif in Austria (Plan, 2005), as determined using the limestone tablet method. But the $R_{\text {aw }}$ of $2.00 \mathrm{~g} \mathrm{~m}^{-2} \mathrm{a}^{-1}$ is lower than the results of 7.0-63.5 $\mathrm{g} \mathrm{m}^{-2} \mathrm{a}^{-1}$ for $R_{\text {aw }}$ from Jinfo Mountain in Chongqing, China (Zhang, 2011). These differences in carbonate weathering are mainly attributed to the different types of carbonate rock tablets, climate, microenvironments of soil, etc. The $R_{\mathrm{aw}}$ of limestone in the $\mathrm{N}$ fertilizer treatments is 20.57-34.71 $\mathrm{g} \mathrm{m}^{-2} \mathrm{a}^{-1}$, similar to the weathering rate of carbonate in an orchard $\left(32.97 \mathrm{~g} \mathrm{~m}^{-2} \mathrm{a}^{-1}\right)$ at Nongla, Manshan, Guangxi, China, which usually involves fertilization activities.

On larger scales, such as watersheds, the weathering rate is usually estimated by using the riverine hydro-chemical method, which is inconsistent with the results from the carbonate rock-tablet test. Zeng et al. (2014) estimate that the carbon sink intensity calculated by the carbonate rock-tablet test is only one sixth of that estimated using the riverine hydro-chemical method (Zeng et al., 2014). The results from Semhi et al. (2000) show that the weathering rates of carbonate rock using the riverine hydro-chemical method are approximately 77.5 and $50.4 \mathrm{~g} \mathrm{~m}^{-2} \mathrm{a}^{-1}$ in the upstream and downstream parts, respectively, of the Garonne River, France, which is approximately 25-35 times greater than that in the control treatment $\left(2.00 \mathrm{~g} \mathrm{~m}^{-2} \mathrm{a}^{-1}\right.$ for natural weathering rate) and 2-3 times greater than in the $\mathrm{N}$ fertilizer treatment (20.57-34.71 $\mathrm{g} \mathrm{m}^{-2} \mathrm{a}^{-1}$ for anthropogenic weathering rate) in this study. The global natural weathering rate of carbonate reported by Amiotte Suchet et al. (2003) is $47.8 \mathrm{~g} \mathrm{~m}^{-2} \mathrm{a}^{-1}$, which is much higher than what we observed. Thus, we conclude that it is difficult to compare the results from the carbonate rock-tablet test and the riverine hydro-chemical method. The carbonate rock-tablet test is suitable for research on the comparative or simulated experiments, while the riverine hydro-chemical method is appropri- ate for regional investigations and estimations. According to the estimation from Yue et al. (2015), the enhanced $\mathrm{HCO}_{3}^{-}$ flux due to the nitrification of $\mathrm{NH}_{4}^{+}$in the Houzhai catchment of Guizhou Province would be $3.72 \times 10^{5} \mathrm{~kg} \mathrm{C}$ year $^{-1}$ and account for $18.7 \%$ of this flux in the entire catchment (Yue et al., 2015). This is similar to estimates from other small agricultural carbonate basins $(12-26 \%)$ in southwest France.

\section{Conclusions}

The impact of the addition of different fertilizers $\left(\mathrm{NH}_{4} \mathrm{NO}_{3}\right.$, $\mathrm{NH}_{4} \mathrm{HCO}_{3}, \quad \mathrm{NaNO}_{3}, \quad \mathrm{NH}_{4} \mathrm{Cl}, \quad\left(\mathrm{NH}_{4}\right)_{2} \mathrm{CO}_{3}, \mathrm{Ca}_{3}\left(\mathrm{PO}_{4}\right)_{2}$, $\left(\mathrm{NH}_{4}\right)_{3} \mathrm{PO}_{4}$, $\mathrm{Ca}-\mathrm{Mg}-\mathrm{P}$, urea and $\mathrm{K}_{2} \mathrm{CO}_{3}$ ) on carbonate weathering was studied in a field column experiment using carbonate rock tablets. The amount of weathering and the ratio of the weathering of carbonate rock tablets showed that the addition of urea, $\mathrm{NH}_{4} \mathrm{NO}_{3}, \mathrm{NH}_{4} \mathrm{HCO}_{3}, \mathrm{NH}_{4} \mathrm{Cl}$ and $\left(\mathrm{NH}_{4}\right)_{2} \mathrm{CO}_{3}$ distinctly increased carbonate weathering, which was attributed to the nitrification of $\mathrm{NH}_{4}^{+}$, while the addition of $\mathrm{Ca}_{3}\left(\mathrm{PO}_{4}\right)_{2}, \mathrm{Ca}-\mathrm{Mg}-\mathrm{P}$ and $\mathrm{K}_{2} \mathrm{CO}_{3}$ induced carbonate precipitation due to the common ion effect. The addition of $\left(\mathrm{NH}_{4}\right)_{3} \mathrm{PO}_{4}$ and $\mathrm{NaNO}_{3}$ had a relatively small impact on carbonate weathering, where the former can be attributed to the low added amount of $\left(\mathrm{NH}_{4}\right)_{3} \mathrm{PO}_{4}$ and may be related to the inhibition of phosphate, while the latter seemed to raise a new question. The problem is that the minor impact of nitrate on carbonate weathering may result in the overestimation of the impact of $\mathrm{N}$ fertilizer on $\mathrm{CO}_{2}$ consumption by carbonate weathering on the regional/global scale if the effects of $\mathrm{NO}_{3}$ and $\mathrm{NH}_{4}$ are not distinguished. Thus, the related anthropogenic inputs (e.g., $\mathrm{Ca}+\mathrm{Mg}, \mathrm{NH}_{4}, \mathrm{NO}_{3}^{-}$and $\mathrm{HCO}_{3}^{-}$) need to be investigated to more accurately estimate the impact of fertilization on carbonate weathering and its 
consumption of $\mathrm{CO}_{2}$ (Perrin et al., 2008; Semhi and Suchet, 2000).

Data availability. No data sets were used in this article.

Competing interests. The authors declare that they have no conflict of interest.

Acknowledgements. This study was supported jointly by the Basic Science Research Fund from the Institute of Hydrogeology and Environmental Geology (grant no. SK201208) and the Chinese National Natural Science Foundation (no. 41403107 and no. 41325010).

Edited by: Robert Hilton

Reviewed by: three anonymous referees

\section{References}

Adams, J. M. and Post, W. M.: A preliminary estimate of changing calcrete carbon storage on land since the Last Glacial Maximum, Global Planet. Change, 20, 243-256, 1999.

Alkattan, M., Oelkers, E. H., Dandurand, J. L., and Schott, J.: An experimental study of calcite dissolution rates at acidic conditions and $25^{\circ} \mathrm{C}$ in the presence of $\mathrm{NaPO}_{3}$ and $\mathrm{MgCl}_{2}$, Chem. Geol., 190, 291-302, 2002.

Amiotte Suchet, P., Probst, J. L., and Ludwig, W.: Worldwide distribution of continental rock lithology: implications for the atmospheric/soil $\mathrm{CO}_{2}$ uptake by continental weathering and alkalinity river transport to the oceans, Global Biogeochem. Cy., 17, 1-13, 2003.

Andrews, J. A. and Schlesinger, W. H.: Soil $\mathrm{CO}_{2}$ dynamics, acidification, and chemical weathering in a temperate forest with experimental $\mathrm{CO}_{2}$ enrichment, Global Biogeochem. Cy., 15, 149-162, 2001.

Barnes, R. T. and Raymond, P. A.: The contribution of agricultural and urban activities to inorganic carbon fluxes within temperate watersheds, Chem. Geol., 266, 318-327, 2009.

Berner, R. A. and Morse, J. W.: Dissolution kinetics of calcium carbonate in sea water; IV, Theory of calcite dissolution, Am. J. Sci., 274, 108-134, 1974.

Bertrand, I., Delfosse, O., and Mary, B.: Carbon and nitrogen mineralization in acidic, limed and calcareous agricultural soils: apparent and actual effects, Soil Biol. Biochem., 39, 276-288, 2007.

Biasi, C., Lind, S. E., Pekkarinen, N. M., Huttunen, J. T. Shurpali, N. J., Hyvönen, N. P., Repo, M. E., and Martikainen, P. J.: Direct experimental evidence for the contribution of lime to $\mathrm{CO}_{2}$ release from managed peat soil, Soil Biol. Biochem., 40, 2660-2669, 2008.

Burton, E. A. and Walter, L. M.: The role of $\mathrm{pH}$ in phosphate inhibition of calcite and aragonite precipitation rates in seawater, Geochim. Cosmochim. Ac., 54, 797-808, 1990.

Calmels, D., Gaillardet, J., and François, L.: Sensitivity of carbonate weathering to soil $\mathrm{CO}_{2}$ production by biological activity along a temperate climate transect, Chem. Geol., 390, 74-86, 2014.
Chien, S. H., Prochnow, L. I., Tu, S., and Snyder, C. S.: Agronomic and environmental aspects of phosphate fertilizers varying in source and solubility: an update review, Nutr. Cycl. Agroecosys., 89, 229-255, 2011.

Chou, L., Garrels, R. M., and Wollast, R.: Comparative study of the kinetics and mechanisms of dissolution of carbonate minerals, Chem. Geol., 78, 269-282, 1989.

Dreybrodt, W.: Reply to the comment by Y. Zhang and CA Grattoni on:"precipitation kinetics of calcite in the system $\mathrm{CaCO}_{3}-\mathrm{H}_{2} \mathrm{O}$ $\mathrm{CO}_{2}$ : the conversion to $\mathrm{CO}_{2}$ by the slow process $\mathrm{H}^{+}+\mathrm{HCO}_{3}^{-} \rightarrow$ $\mathrm{CO}_{2}+\mathrm{H}_{2} \mathrm{O}$ as a rate limiting step" by W. Dreybrodt, L. Eisenlohr, B. Madry, and S. Ringer, Geochim. Cosmochim. Ac., 62, 3791-3792, 1998.

Dreybrodt, W., Lauckner, J., Zaihua, L., Svensson, U., and Buhmann, D.: The kinetics of the reaction $\mathrm{CO}_{2}+\mathrm{H}_{2} \mathrm{O}$ ? $\mathrm{H}^{+}+\mathrm{HCO}_{3}^{-}$ as one of the rate limiting steps for the dissolution of calcite in the system $\mathrm{H}_{2} \mathrm{O}-\mathrm{CO}_{2}-\mathrm{CaCO}_{3}$, Geochim. Cosmochim. Ac., 60, 3375-3381, 1996.

Egli, M. and Fitze, P.: Quantitative aspects of carbonate leaching of soils with differing ages and climates, Catena, 46, 35-62, 2001.

Errin, A. S. P., Robst, A. P., and Robst, J. L. P.: Impact of nitrogen fertilizers on natural weathering processes: evident role on $\mathrm{CO}_{2}$ consumption the oxygen isotopic composition of Precambrian cherts, Goldschmidt Conference, Melbourne, AUSTRALIA (27 August-1 September 2006), 2332-2332, 2006.

Etchanchu, D. and Probst, J.: Evolution of the chemical composition of the Garonne River water during the period 1971-1984, Hydrolog. Sci. J., 33, 243-256, 1988.

FAO: Fertilizer requirements in 2015 and 2030, Rome, FAO, 2000.

Gams, I.: Comparative research of limestone solution by means of standard tablets, Proceedings of the 8th International Congress of Speleology Bowling Green, Kentucky, 18 to 24 July 1981, 1981 273-275, 1981.

Gams, I.: International comparative measurements of surface solution by means of standard limestone tablets, Razpr IV Razeda Sazu, 26, 361-386, 1985.

Gandois, L., Perrin, A. S., and Probst, A.: Impact of nitrogenous fertiliser-induced proton release on cultivated soils with contrasting carbonate contents: a column experiment, Geochim. Cosmochim. Ac., 75, 1185-1198, 2011.

GBS: 2014 Guizhou Statistical Yearbook, Statistical Press of China, Beijing, 2014.

Giannimaras, E. K. and Koutsoukos, P. G.: The crystallization of calcite in the presence of orthophosphate, J. Colloid Interf. Sci., 116, 423-430, 1987.

Hagedorn, B. and Cartwright, I.: Climatic and lithologic controls on the temporal and spatial variability of $\mathrm{CO}_{2}$ consumption via chemical weathering: an example from the Australian Victorian Alps, Chem. Geol., 260, 234-253, 2009.

Hamilton, S. K., Kurzman, A. L., Arango, C., Jin, L., and Robertson, G. P.: Evidence for carbon sequestration by agricultural liming, Global Biogeochem. Cy., 21, 1-12, 2007.

Han, Z. and Jin, Z.: Hydrogeology of Guizhou Province, China, Seismic Publication, Beijing, 1996.

House, W. A.: Inhibition of calcite crystal growth by inorganic phosphate, J. Colloid Interf. Sci., 119, 505-511, 1987.

Hunter, A. H.: Soil Fertility analytical services in Bangladesh, BARC/IDAS Cosultancy Report Contract Aid/388-0005, 
Dhaka, Bangladesh Agricultural Research Council, 581-601, 1984.

Ishikawa, M. and Ichikuni, M.: Coprecipitation of phosphate with calcite, Geochem. J., 15, 283-288, 1981.

Jiang, Y.: The contribution of human activities to dissolved inorganic carbon fluxes in a karst underground river system: evidence from major elements and $\delta^{13} \mathrm{C}_{\text {DIC }}$ in Nandong, Southwest China, J. Contam. Hydrol., 152, 1-11, 2013.

Jiang, Y., Wu, Y., Groves, C., Yuan, D., and Kambesis, P.: Natural and anthropogenic factors affecting the groundwater quality in the Nandong karst underground river system in Yunan, China, J. Contam. Hydrol., 109, 49-61, 2009.

Jiang, Z. and Yuan, D.: $\mathrm{CO}_{2}$ source-sink in karst processes in karst areas of China, Episodes, 22, 33-35, 1999.

Kiefer, R. H.: Temporal cycles of karst denudation in northwest Georgia, USA, Earth Surf. Proc. Land., 19, 213-232, 1994.

Kitano, Y., Okumura, M., and Idogaki, M.: Uptake of phosphate ions by calcium carbonate, Geochem. J., 12, 29-37, 1978.

Kump, L. R., Brantley, S. L., and Arthur, M. A.: Chemical weathering, atmospheric $\mathrm{CO}_{2}$, and climate, Annu. Rev. Earth Pl. Sc., 28, 611-667, 2000.

Lang, Y.: Geochemistry of surface and ground water in Guiyang, China: water/rock interaction and pollution in a karst hydrological system, Appl. Geochem., 21, 887-903, 2006.

Lerman, A. and $\mathrm{Wu}, \mathrm{L} .: \mathrm{CO}_{2}$ and sulfuric acid controls of weathering and river water composition, J. Geochem. Explor., 88, 427430, 2006.

Lerman, A., Wu, L., and Mackenzie, F. T.: $\mathrm{CO}_{2}$ and $\mathrm{H}_{2} \mathrm{SO}_{4}$ consumption in weathering and material transport to the ocean, and their role in the global carbon balance, Mar. Chem., 106, 326350, 2007.

Li, S., Calmels, D., Han, G., Gaillardet, J., and Liu, C.: Sulfuric acid as an agent of carbonate weathering constrained by $\delta^{13} \mathrm{C}_{\mathrm{DIC}}$ : examples from Southwest China, Earth Planet. Sc. Lett., 270, 189199, 2008.

Li, S., Xu, Z., Wang, H., Wang, J., and Zhang, Q.: Geochemistry of the upper Han River basin, China: 3: Anthropogenic inputs and chemical weathering to the dissolved load, Chem. Geol., 264, 89-95, 2009.

Li, S., Liu, C.-Q., Patra, S., Wang, F., Wang, B., and Yue, F.: Using a dual isotopic approach to trace sources and mixing of sulphate in Changjiang Estuary, China, Appl. Geochem., 26, S210-S213, 2011

Lian, B., Chen, Y., Zhu, L., and Yang, R.: Effect of Microbial Weathering on Carbonate Rocks, Earth Science Frontiers, 15, 90-99, 2008.

Lin, Y. P. and Singer, P. C.: Inhibition of calcite precipitation by orthophosphate: speciation and thermodynamic considerations, Geochim. Cosmochim. Ac., 70, 2530-2539, 2006.

Liu, C., Li, S., Lang, Y., and Xiao, H.: Using $\delta^{15} \mathrm{~N}$ - and $\delta^{18} \mathrm{O}-$ Values To Identify Nitrate Sources in Karst Ground Water, Guiyang, Southwest China, Environ. Sci. Technol., 40, 69286933, 2006.

Liu, Z. and Dreybrod, W.: Dissolution kinetics of calcium carbonate minerals in $\mathrm{H}_{2} \mathrm{O}-\mathrm{CO}_{2}$ solutions in turbulent flow: the role of the diffusion boundary layer and the slow reaction $\mathrm{H}_{2} \mathrm{O}+\mathrm{CO}_{2} \leftrightarrow$ $\mathrm{H}^{+}+\mathrm{HCO}_{3}^{-}$, Geochim. Cosmochim. Ac., 61, 2879-2889, 1997.

Liu, Z., Dreybrodt, W., and Wang, H.: A new direction in effective accounting for the atmospheric $\mathrm{CO}_{2}$ budget: considering the combined action of carbonate dissolution, the global water cycle and photosynthetic uptake of DIC by aquatic organisms, EarthSci. Rev., 99, 162-172, 2010.

Liu, Z., Dreybrodt, W., and Liu, H.: Atmospheric $\mathrm{CO}_{2}$ sink: silicate weathering or carbonate weathering?, Appl. Geochem., 26, 292 294, 2011.

Mucci, A.: Growth kinetics and composition of magnesian calcite overgrowths precipitated from seawater: quantitative influence of orthophosphate ions, Geochim. Cosmochim. Ac., 50, 22552265, 1986.

NBS: 2014 Statistical Yearbook, Statistical Press of China, Beijing, 2014.

Oh, N. and Raymond, P. A.: Contribution of agricultural liming to riverine bicarbonate export and $\mathrm{CO}_{2}$ sequestration in the Ohio River basin, Global Biogeochem. Cy., 20, 1-17, 2006.

Perrin, A., Probst, A., and Probst, J.: Impact of nitrogenous fertilizers on carbonate dissolution in small agricultural catchments: implications for weathering $\mathrm{CO}_{2}$ uptake at regional and global scales, Geochim. Cosmochim. Ac., 72, 3105-3123, 2008.

Pierson-Wickmann, A., Aquilina, L., Martin, C., Ruiz, L., and Molénat, J.: High chemical weathering rates in first-order granitic catchments induced by agricultural stress, Chem. Geol., 265, 369-380, 2009.

Plan, L.: Factors controlling carbonate dissolution rates quantified in a field test in the Austrian alps, Geomorphology, 68, 201-212, 2005.

Plummer, L. N., Wigley, T., and Parkhurst, D. L.: The kinetics of calcite dissolution in $\mathrm{CO}_{2}$-water systems at 5 to $60^{\circ} \mathrm{C}$ and 0.0 to 1 atm $\mathrm{CO}_{2}$, Am. J. Sci., 278, 179-216, 1978.

Pokrovsky, O. S., Golubev, S. V., Schott, J., and Castillo, A.: Calcite, dolomite and magnesite dissolution kinetics in aqueous solutions at acid to circumneutral $\mathrm{pH}, 25$ to $150^{\circ} \mathrm{C}$ and 1 to $55 \mathrm{~atm}$ $p \mathrm{CO}_{2}$ : new constraints on $\mathrm{CO}_{2}$ sequesration in sedimentary basins, Chem. Geol., 265, 20-32, 2009.

Probst, J.: Dissolved and suspended matter transported by the Girou River (France): mechanical and chemical erosion rates in a calcareous molasse basin, Hydrolog. Sci. J., 31, 61-79, 1986.

Raistrick, B.: The influence of foreign ions on crystal growth from solution. 1. The stabilization of the supersaturation of calcium carbonate solutions by anions possessing OPOPO chains, Discuss. Faraday Soc., 5, 234-237, 1949.

Reddy, M. M.: Crystallization of calcium carbonate in the presence of trace concentrations of phosphorus-containing anions: I. Inhibition by phosphate and glycerophosphate ions at $\mathrm{pH} 8.8$ and $25^{\circ} \mathrm{C}$, J. Cryst. Growth, 41, 287-295, 1977.

Semhi, K. and Suchet, A.: Impact of nitrogen fertilizers on the natural weathering-erosion processes and fluvial transport in the Garonne basin, Appl. Geochem., 15, 865-878, 2000.

Shin, W., Ryu, J., Mayer, B., Lee, K., and Lee, S.: Natural and anthropogenic sources and processes affecting water chemistry in two South Korean streams, Sci. Total Environ., 485, 270-280, 2014.

Singh, J., Kunhikrishnan, A., Bolan, N. S., and Saggar, S.: Impact of urease inhibitor on ammonia and nitrous oxide emissions from temperate pasture soil cores receiving urea fertilizer and cattle urine, Sci. Total Environ., 465, 56-63, 2013.

Soares, J. R., Cantarella, H., and Menegale, M. L. D. C.: Ammonia volatilization losses from surface-applied urea with urease and nitrification inhibitors, Soil Biol. Biochem., 52, 82-89, 2012. 
Song, C., Liu, C., Wang, J., Zhang, Y., and Hou, H.: Impact of the addition of a compound fertilizer on the dissolution of carbonate rock tablets: a column experiment, Appl. Geochem., 26, 170$173,2011$.

Song, C., Liu, C., Zhang, Y., and Hou, H.: Impact of animal manure addition on agricultural lime weathering in acidic soil: $\mathrm{pH}$ dependence and $\mathrm{CO}_{2}$ independence of agricultural lime weathering, Proced. Earth Plan. Sc., 10, 405-409, 2014.

Song, C., Liu, C., and Han, G.: Impact of fertilization with irrigation on carbonate weathering in an agricultural soil in Northern China: a column experiment, Geochem. J., 51, 143-155, 2017a.

Song, C., Liu, C., Zhang, Y., and Hou, H.: Impact of animal manure addition on the weathering of agricultural lime in acidic soils: the agent of carbonate weathering, Journal of Groundwater Science and Engineering, 2, 202-212, 2017b.

Trudgill, S. T.: Measurement of erosional weight loss of rock tablets, British Geomorphological Research Group Technical Bulletin, 17, 13-20, 1975.

Trypuc, M. and Kielkowska, U.: Solubility in the $\mathrm{NH}_{4} \mathrm{HCO}_{3}+$ $\mathrm{NH}_{4} \mathrm{VO}_{3}+\mathrm{H}_{2} \mathrm{O}$ system, J. Chem. Eng. Data., 41, 1005-1007, 1996.
Wang, L., Ruiz-Agudo, E., Putnis, C. V., Menneken, M., and Putnis, A.: Kinetics of calcium phosphate nucleation and growth on calcite: implications for predicting the fate of dissolved phosphate species in alkaline soils, Environ. Sci. Technol., 46, 834842, 2012.

West, T. O. and McBride, A. C.: The contribution of agricultural lime to carbon dioxide emissions in the United States: dissolution, transport, and net emissions, Agr. Ecosyst. Environ., 108, 145-154, 2005.

Yue, F. J., Li, S. L., Liu, C. Q., Lang, Y. C., and Ding, H.: Sources and transport of nitrate constrained by the isotopic technique in a karst catchment: an example from Southwest China, Hydrol. Process., 29, 1883-1893, 2015.

Zeng, C., Zhao, M., Yang, R., and Liu, Z.: Comparison of karst processes-related carbon sink intensity calculated by carbonate rock tablet test and solute load method: a case study in the Chenqi karst spring system, Hydrogology and Engineering Geology, 41, 106-111, 2014.

Zhang, C.: Carbonate rock dissolution rates in different landuses and their carbon sink effect, Chinese Sci. Bull., 56, 3759-3765, 2011. 